Article

\title{
Exploring the Biotechnological Value of Marine Invertebrates: A Closer Look at the Biochemical and Antioxidant Properties of Sabella spallanzanii and Microcosmus squamiger
}

\author{
Yu-Lun Pan ${ }^{1}$, Maria João Rodrigues ${ }^{1}$, Catarina G. Pereira ${ }^{1} \oplus$, Sofia Engrola ${ }^{1} \oplus$, Rita Colen ${ }^{1} \oplus$, Inês Mansinhos ${ }^{2}{ }^{\oplus}$, \\ Anabela Romano ${ }^{2}$, Paula B. Andrade ${ }^{3}$, Fátima Fernandes $^{3}$ (D) and Luísa Custódio $1, *(\mathbb{D})$ \\ 1 Centre of Marine Sciences (CCMAR), Faculty of Sciences and Technology, Campus of Gambelas, Ed. 7, \\ University of Algarve, 8005-139 Faro, Portugal; yulun.pan@imbrsea.eu (Y.-L.P.); mjrodrigues@ualg.pt (M.J.R.); \\ cagpereira@ualg.pt (C.G.P.); sengrola@ualg.pt (S.E.); rcolen@ualg.pt (R.C.) \\ 2 MED-Mediterranean Institute for Agriculture, Environment and Development, Faculty of Sciences and \\ Technology, Campus de Gambelas, Ed. 8, University of Algarve, 8005-139 Faro, Portugal; \\ ifmansinhos@ualg.pt (I.M.); aromano@ualg.pt (A.R.) \\ 3 REQUIMTE/LAQV: Laboratório de Farmacognosia, Departamento de Química, Faculdade de Farmácia, \\ Universidade do Porto, Rua de Jorge Viterbo Ferreira n. 228, 4050-313 Porto, Portugal; \\ pandrade@ff.up.pt (P.B.A.); mfgfernandes@gmail.com (F.F.) \\ * Correspondence: lcustodio@ualg.pt
}

Citation: Pan, Y.-L.; Rodrigues, M.J.; Pereira, C.G.; Engrola, S.; Colen, R.; Mansinhos, I.; Romano, A.; Andrade, P.B.; Fernandes, F.; Custódio, L. Exploring the Biotechnological Value of Marine Invertebrates: A Closer Look at the Biochemical and Antioxidant Properties of Sabella spallanzanii and Microcosmus squamiger. Animals 2021, 11, 3557. https://doi.org/10.3390/ani11123557

Academic Editor: Frank Dunshea

Received: 12 October 2021

Accepted: 8 December 2021

Published: 14 December 2021

Publisher's Note: MDPI stays neutral with regard to jurisdictional claims in published maps and institutional affiliations.

Copyright: (c) 2021 by the authors. Licensee MDPI, Basel, Switzerland. This article is an open access article distributed under the terms and conditions of the Creative Commons Attribution (CC BY) license (https:// creativecommons.org/licenses/by/ $4.0 /)$.
Simple Summary: Marine invertebrates are a rich source of natural products with multiple commercial applications. However, little is known about the biotechnological potential of Sabella spallanzanii and Microcosmus squamiger. Aimed at filling this gap, this work evaluated such species for biochemical, antioxidant and metal chelating properties. Both species had interesting nutritional profiles in terms of crude protein and fat, among others. Regarding amino acids, S. spallanzanii and M. squamiger were found to be rich in arginine and taurine, respectively, while the most abundant minerals were sodium, calcium, and potassium, in both species. Methanol extracts of both species had antioxidant and metal chelating capacity. Fucoxanthinol and fucoxanthin were the major carotenoids in the M. squamiger dichloromethane extract. The fatty acid (FA) profile was strongly influenced by the type of extract. Saturated FA were higher than unsaturated ones in methanol extracts, while unsaturated FA prevailed in the dichloromethane extracts. Low $n-6 / n-3$ ratios were obtained. Our results suggest both species as sustainable sources of bioactive products with several applications, for example, as food ingredients, as fish feed, and as ingredients for veterinary products.

\begin{abstract}
Sabella spallanzanii and Microcosmus squamiger were profiled for proximate composition, minerals, amino acids, fatty acids (FA), carotenoids, radical scavenging activity on the 2,2-diphenyl-1picrylhydrazyl (DPPH) radical, oxygen radical absorbance capacity (ORAC) and iron and copper chelating properties. Microcosmus squamiger had the highest level of moisture and crude protein, S. spallanzanii was enriched in crude fat and ash. Both species had similar levels of carbohydrates and energy. There was a prevalence of arginine and glycine in S. spallanzanii, and of taurine in M. squamiger. The most abundant minerals in both species were $\mathrm{Na}, \mathrm{Ca}$, and $\mathrm{K}$. The methanol extract of $\mathrm{S}$. spallanzanii had metal chelating properties towards copper and iron, while the methanol extract of $M$. squamiger was able to chelate copper. M. squamiger extracts had similar ORAC values. Fucoxanthinol and fucoxanthin were the major carotenoids in the M. squamiger dichloromethane extract. Saturated FA were more abundant than unsaturated ones in methanol extracts, and unsaturated FA prevailed in the dichloromethane extracts. Palmitic acid was the predominant FA in methanol extracts, whereas eicosapentaenoic (EPA) and dihomo- $\gamma$-linolenic acids were the major compounds in dichloromethane extracts. Low $n-6 / n-3$ ratios were obtained. Our results suggests that both species could be explored as sources of bioactive ingredients with multiple applications.
\end{abstract}


Keywords: marine invertebrates; marine biotechnology; natural antioxidants; nutritional profile; carotenoids; fatty acids

\section{Introduction}

More than 40,000 marine natural products (MNPs) have been identified, from several organisms, including macro- and micro-algae and different taxa of invertebrates, such as sponges, cnidarians, tunicates, mollusks, echinoderms, and bryozoans [1]. Research on MNP has focused on marine invertebrates, which produce a plethora of primary and secondary metabolites vital to complex adaptation mechanisms to the marine life conditions, including defense from predators, competitors, and infective agents, coping with salinity and UV radiation, and inter-individual signalization [2]. Such metabolites belong to different classes (e.g., polyketides, terpenoids, alkaloids, lipids), exhibit highly relevant pharmacological properties, (e.g., antioxidant, anti-inflammatory, anti-tumoral), and have multiple industrial applications, for example, in the food, cosmetic and aquaculture sectors.

The Mediterranean fan worm Sabella spallanzanii (Gmelin, 1791) (Phylum: Annelida, Class: Polychaeta) (Figure 1A) is a native species from the temperate zone of the Mediterranean Sea and Southern European Atlantic coast and is an invasive species in Australia and New Zealand [3-5]. It is commonly found on the sediment substrate or artificial hard surfaces to a depth of $30 \mathrm{~m}$ and is part of the diet of several fish species and invertebrates, including cephalopods [6]. Moreover, S. spallanzanii is a suspension feeder and can filter high quantities of water and accumulate metals in its tissues and is therefore considered a suitable biomonitor for metal pollution in marine areas [4,7-9]. Marine invertebrates, including Polychaeta, are widely used as feed ingredients, especially in diets for shrimp [6]. Sabella spallanzanii is a potential candidate for bioremediation of aquaculture waste [6,7], and a potential resource for the fish feed industry due its biochemical profile, especially its high protein and gross energy levels, mineral and fatty acids profile, high concentration of glycosaminoglycan (GAGs), and high levels of amino acids (e.g., glutamic acid, arginine, glycine) that are considered as attractants for different commercial fish species [6]. Microcosmus squamiger (Michaelsen, 1927) (Phylum: Chordata, Class: Ascidiaceae) (Figure 1B) is a cosmopolitan sessile species native to Australia, and is biologically invasive in several areas, including the Iberian Peninsula Atlantic, Mediterranean, North Africa Atlantic, Red Sea, East Pacific, and Indian ocean [10-17]. Moreover, recent findings show that M. squamiger has spread from the western Mediterranean to the eastern Mediterranean [18], and to the west coast of North America [19]. In its natural condition, M. squamiger inhabits hard littoral substrates in a depth up to $10 \mathrm{~m}$ [10], while in the introduced range, it can be found not only in high densities in open coastal habitats where it affects native biota, but also in artificial structures, such as shipping harbors, where it forms dense clumps covering the available substratum [20,21], and also competing for space in cultured bivalves [17]. Information regarding the biochemical properties of $M$. squamiger is limited to the composition of the tunic of this species [22], and to the levels of moisture, lipids, protein, and ash [23] and metals [24] of individuals collected in India. A closely related species, M. exasperates, has a balanced nutritional profile, and contains several bioactive molecules, including vitamins (e.g., D3, K, riboflavin), phenolic compounds (e.g., gallic acid, ferulic acid) and flavonoids (e.g., rutin, quercetin) [25].

Invasive species have severe economic and ecological impacts [26-29]. There are several strategies to control invasive species, and one of the most effective is their use as sources of products with commercial applications [27], which is being exploited for the control of different invasive macroalgae species [27-29]. In this context and having in mind existing information regarding the biochemical properties of $S$. spallanzanii and M. squamiger, and the fact that both species can co-exist in the same location, this work aimed to determine if both species could be exploited in the context of blue biotechnology as sources of nutritional and bioactive compounds. For this purpose, we have focused on the 
nutritional profile of the animal's biomass, including proximate composition, minerals, and amino acids levels, and on the fatty acids (FA), carotenoid contents, and on the antioxidant properties of methanol and dichloromethane extracts obtained from said biomass.

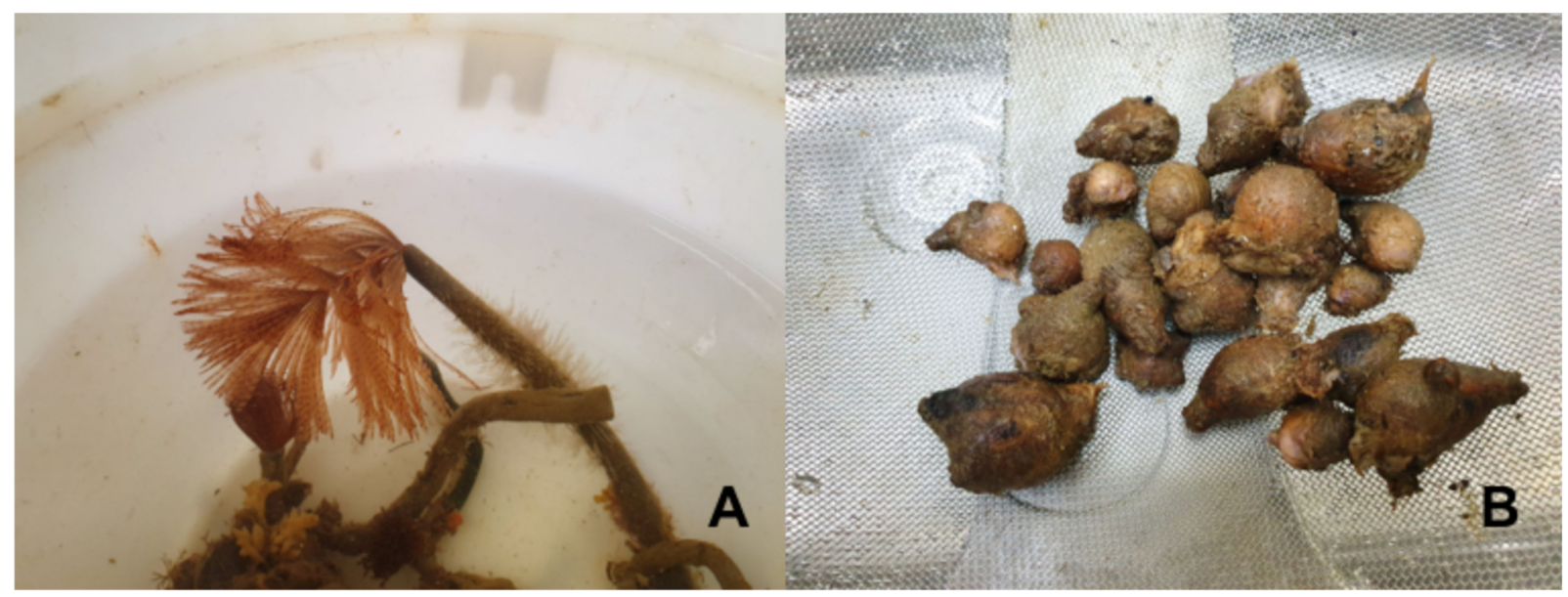

Figure 1. Collected specimens of Sabella spallanzanii (A) and Microcosmus squamiger (B). (Photo by Yu Lun-Pan).

\section{Materials and Methods}

\subsection{Chemicals}

All reagents and solvents were of analytical grade. Sodium acetate, 2,2-diphenyl-1picrylhydrazyl (DPPH), potassium dihydrogen phosphate and pure standards of amino acids were purchased from Sigma-Aldrich (Lisbon, Portugal). 2,20-azobis (2-amidinopropane) dihydrochloride (AAPH) and 6-hydroxy-2,5,7,8-teramethylchroman-2-carboxylic acid (Trolox) were acquired from Acros Organics (Geel, Belgium). Panreac Química (Castellar Del Valles, Spain) provided fluorescein and nitric acid. Dimethyl sulfoxide (DMSO), ethylenediamine tetraacetic acid (EDTA), copper (II) sulfate, and additional chemicals were obtained from VWR International (Leuven, Belgium). A mixed standard solution of fatty acid methyl esters (FAME) (CRM47885) was obtained from Supelco (Bellefonte, PA, USA). Chloroform, iso-octane, boron trifluoride (BF3)-methanol solution, potassium hydroxide $(\mathrm{KOH})$ and anhydrous sodium sulphate were purchased from Sigma-Aldrich (St. Louis, MO, USA). Methanol was acquired from VWR (Fontenay-sous-Bois, France). Standards of fucoxanthin $(\geq 95.0 \%)$ and $\beta$-carotene $(\geq 95.0 \%)$, and methyl tert-butyl ether (MTBE) were purchased from Sigma-Aldrich (St. Louis, MO, USA). Standards of astaxanthin (95.0\%), antheraxanthin $(\geq 95.0 \%)$, zeaxanthin $(97.0 \%), \varepsilon, \varepsilon$-carotene, $\alpha$-carotene and $\gamma$-carotene were obtained from CaroteNature (Lupsinggen, Switzerland). Fucoxanthinol $(\geq 95.0 \%)$ was from FLuka (Buchs, Switzerland). Methanol (MeOH) Lichrosolv was acquired from Merck (Darmstadt, Germany).

\subsection{Sampling}

Adult specimens of S. spallanzanii and M. squamiger (Figure 1) were hand-collected as a bulk from the floating dock in Faro, Portugal $\left(37^{\circ} 00^{\prime} 15.4^{\prime \prime} \mathrm{N} 7^{\circ} 59^{\prime} 16.8^{\prime \prime} \mathrm{W}\right)$ in January 2020 and transported to the Centre of Marine Sciences (CCMAR, University of Algarve, Gambelas Campus). Species identification was conducted by traditional taxonomic characters by Dr. Carlos Afonso from the Fisheries, Biodiversity and Conservation research group from CCMAR. The polychaetes and ascidians were separated, and samples were rinsed with tap water, followed by distilled water, to remove contaminants. Samples were freeze-dried, milled, and stored at $-20^{\circ} \mathrm{C}$.

\subsection{Proximate Composition}

Moisture was measured by drying the fresh biomass at $60^{\circ} \mathrm{C}$ until constant weight, while ash was determined by incineration in a muffle furnace at $525{ }^{\circ} \mathrm{C}$ for $5 \mathrm{~h}$. The 
crude protein content was determined by the elemental analysis of nitrogen $(\mathrm{N})$, in a combustion analyzer. The $\mathrm{N}$ value was then multiplied by the conversion factor (6.25) to determine the crude protein [30]. Total lipids were determined by the modified method from Bligh and Dyer, as described previously [31]. Carbohydrates were calculated by difference. The gross energy (GE) was calculated using the Atwater general factor system: $\mathrm{GE}(\mathrm{MJ})=0.017878 \times(\mathrm{g}$ protein $)+0.037765 \times(\mathrm{g}$ lipid $)$. Results were presented as percentages for moisture, ash, protein, and fat. GE was represented as MJ/kg of dry weight biomass (dw).

\subsection{Amino Acids}

The tissues levels in free amino acids were determined by ultra-high performance liquid chromatography (UPLC). In brief, freeze dried samples were homogeneized in hydrogen chloride $(\mathrm{HCl}, 0.1 \mathrm{M})$ on ice, and centrifuged $\left(1500 \times g, 4{ }^{\circ} \mathrm{C}, 15 \mathrm{~min}\right)$. The supernatant was collected and deproteinized by centrifugal ultrafiltration (10 kDa cut-off, $2500 \times g$ at $4{ }^{\circ} \mathrm{C}$ for $\left.20 \mathrm{~min}\right)$. Samples were pre-column derivatized with the Waters AccQ fluor reagent (6-aminoquinolyl-N-hydroxysuccinimidyl carbamate) using the AccQ Tag method (Waters, USA). Analyses were performed by UPLC on a Waters reversed-phase amino acid analysis system, using norvaline as an internal standard. Amino acids were identified by comparing their retention times with those of standard mixtures and pure standards. Instrument control, data acquisition and processing were achieved using Waters Empower software (Milford, MA, USA).

\subsection{Minerals}

Dried biomass $(25 \mathrm{mg})$ was digested with nitric acid $\left(\mathrm{HNO}_{3}, 6 \mathrm{~mL}\right)$ and hydrogen peroxide $\left(\mathrm{H}_{2} \mathrm{O}_{2}, 2 \mathrm{~mL}\right)$ using a CEM Discover microwave synthesizer (Matthews, NC, USA). The resulting solutions were diluted in ultrapure water to give sample solutions in serial concentrations. The concentrations of minerals in the sample solutions were analyzed using Agilent 4200 microwave plasma-atomic emission spectroscopy (MP-AES) (Santa Clara, CA, USA). The calibration curve was obtained by referring to the multielement standard solution. Agilent MP Expert software (Santa Clara, CA, USA) was used to subtract the background signal from the analytical signal and data acquisition.

\subsection{Preparation of the Extracts}

Dried biomass ( $1 \mathrm{~g}$ ) was separately extracted with dichloromethane or methanol $(40 \mathrm{~mL})$ during $30 \mathrm{~min}$ in an ultrasound bath (USC-TH, VWR, Portugal), with a capacity for $5.4 \mathrm{~L}$, frequency of $45 \mathrm{kHz}$, a supply of $230 \mathrm{~V}$ and a tub heater of $400 \mathrm{~W}$, at room temperature (RT). The extracts were then filtered (Whatman $\mathrm{n}^{\circ} 4$ ) and evaporated under controlled temperature $\left(\leq 45^{\circ} \mathrm{C}\right)$ and pressure in a rotary evaporator (BUCHI R -210, Flawil, Switzerland). The obtained dried extracts were resuspended in DMSO for the carotenoid's determination, and for antioxidant activity and metal chelating assays, and in iso-octane for the fatty acids analysis.

\subsection{Chemical Characterization of the Extracts}

\subsubsection{FA Determination}

For FA characterization, the extracts were subjected to an alkaline hydrolysis to obtain free fatty acids and derivatized to obtain the corresponding methyl esters (FAME), being then analysed by gas chromatography (GC-FID), as described previously [32]. Samples $(1 \mu \mathrm{L})$ were injected in triplicate, and the levels of FAME present were obtained from calibration curves of the respective standards using at least six concentrations of the analytes, according to the range of concentrations found in the samples. The limit of detection (LOD) and limit of quantification (LOQ) (Table S1, Supplementary Materials) were determined from the calibration curves, according to the following formula:

$$
\mathrm{LOD}=3 \times \mathrm{SD}
$$




$$
\mathrm{LOQ}=10 \times \mathrm{SD}
$$

where SD is the residual standard deviation of the linear regression (Table S1, Supplementary Materials).

\subsubsection{HPLC-DAD Analysis for Carotenoid Determination}

The carotenoid contents of the extracts were determined by liquid chromatography (HPLC-DAD), as described elsewhere [32,33]. Identification of the compounds was achieved by comparing their retention times and UV-Vis spectra in the range of 200-700 nm with those of pure standards. Peak purity was assured by the software contrast facilities and pigment quantification was accomplished by the absorbance verified in the chromatograms (at $450 \mathrm{~nm}$ ) in relation to external calibration curves, which were obtained by using, at least, six different concentration levels of the standards, according to the array of concentrations detected in the samples. LOD and LOQ were determined from the calibration curves (Table S2, Supplementary Materials), according to Equations (1) and (2).

\subsection{In Vitro Radical Scavenging Activity (RSA) of the Extracts}

\subsubsection{RSA on DPPH}

The RSA towards DPPH was determined according to Rodrigues et al. [34] on samples ranging from 0 to $10 \mathrm{mg} / \mathrm{mL}$. Absorbances were read at $492 \mathrm{~nm}$ in a microplate reader (Biochrome EZ400), and RSA was calculated in relation to the blank containing DMSO. Results were expressed as half maximal inhibitory concentration ( $\mathrm{IC}_{50}$ values), when possible. Butylated hydroxytoluene (BHT) was used as the positive control at $1 \mathrm{mg} / \mathrm{mL}$.

\subsubsection{Oxygen Radical Absorbance Capacity (ORAC) Assay}

ORAC was measured following the method described by Gillespie et al. [35] on extracts diluted to adequate concentrations in relation to Trolox. The decrease in fluorescence was established by reading fluorescein excitation at $485 \mathrm{~nm}$ and emission at $530 \mathrm{~nm}$, for a period of $90 \mathrm{~min}$, each minute, in a microplate reader (Tecan Infinite M200 multi detection plate reader). ORAC results were calculated using the area under the curve (AUC) and results were expressed as mmol of Trolox equivalents per $100 \mathrm{~g}$ of dry weight (mmol TE/100 g).

\subsection{In Vitro Metal Chelating Properties of the Extracts}

Copper (CCA) and Iron (ICA) Chelating Activity

CCA and ICA were determined by the methods described by Rodrigues et al. [34], on the extracts at concentrations up to $10 \mathrm{mg} / \mathrm{mL}$. EDTA $(1 \mathrm{mg} / \mathrm{mL})$ and DMSO were used as positive and negative controls, respectively. Absorbance was measured at $620 \mathrm{~nm}$ for copper and $562 \mathrm{~nm}$ for iron, in a microplate reader (Biochrome EZ400). Results were calculated in relation to the negative control and expressed as $\mathrm{IC}_{50}$ values whenever possible.

\subsection{Statistical Analyses}

Statistical analysis was performed using SPSS Statistics software v. 22 (IBM SPSS Statistics for Windows, IBM Corp., Armonk, NY, USA). Analyses were conducted at least in triplicate and expressed as mean \pm standard error of the mean (SEM) or as mean \pm standard deviation. A one-way analysis of variance (ANOVA) with Tukey's HSD post hoc test $(p<0.05)$ was used to look for statistically significant differences among results. Differences amongst samples were considered significant if $p$ values were equal or inferior to 0.05 . The $\mathrm{IC}_{50}$ values were determined through data sigmoidal fitting in the GraphPad Prism v. 5.0 software (San Diego, CA, USA).

\section{Results}

\subsection{Proximate Composition}

The proximate composition and energetic value of $S$. spallanzanii and M. squamiger can be found in Table 1. The moisture, ash, and total levels of protein and lipid of $S$. spallanzanii 
were $70.7 \%, 53.1 \%, 47.2 \%$ and $11.7 \%$, while those of $M$. squamiger were $88.9 \%, 36.2 \%, 53.9 \%$ and $5.3 \%$. The calculated gross energy was $12.8 \mathrm{MJ} / \mathrm{kg}$ for S. spallanzanii, and $11.6 \mathrm{MJ} / \mathrm{kg}$ for M. squamiger.

Table 1. Proximate composition and energetic value of the biomass of Sabella spallanzanii and Microcosmus squamiger.

\begin{tabular}{ccc}
\hline Item & S. spallanzanii & M. squamiger \\
\hline Moisture (\%) & $70.7 \pm 1.0$ & $88.9 \pm 0.8$ \\
\hline Ash $(\%)$ & $53.1 \pm 4.8$ & $36.2 \pm 4.6$ \\
\hline Protein $(\%, \mathrm{dw})$ & $47.2 \pm 0.3$ & $53.9 \pm 2.6$ \\
\hline Fat $(\%, \mathrm{dw})$ & $11.7 \pm 1.7$ & $5.3 \pm 0.1$ \\
\hline Carbohydrates $(\%, \mathrm{dw})$ & $41.1 \pm 1.4$ & $40.8 \pm 2.6$ \\
\hline Energetic value $(\mathrm{kcal} / 100 \mathrm{~g}, \mathrm{dw})$ & $475.8 \pm 8.1$ & $445.6 \pm 0.4$ \\
\hline
\end{tabular}

Data represent the mean \pm standard error of mean (SEM) $(n=3)$. dw: dry weight.

\subsection{Amino Acids}

A total of 26 free amino acids (FAA) were identified, representing $131.76 \mathrm{mg} / \mathrm{g}(\mathrm{dw})$ in S. spallanzanii and $52.42 \mathrm{mg} / \mathrm{g}(\mathrm{dw})$ in M. squamiger (Table 2). The predominant amino acid in S. spallanzanii was arginine $(68.5 \mathrm{mg} / \mathrm{g}, \mathrm{dw})$, corresponding to $2008 \mathrm{mg} / 100 \mathrm{~g}$ (wet weight, ww), followed by glycine (49.3\%), while the content of the remaining FAA varied from $0.03 \mathrm{mg} / \mathrm{g}$ (tryptophan) to $2.30 \mathrm{mg} / \mathrm{g}$ (taurine). The most abundant FAA in M. squamiger was taurine $(26.64 \mathrm{mg} / \mathrm{g}$, dw, corresponding to $296 \mathrm{mg} / 100 \mathrm{~g}$, ww), while the levels of the other amino acids ranged from $0.15 \mathrm{mg} / \mathrm{g}$ (cysteine) to $5.15 \mathrm{mg} / \mathrm{g}$ (proline).

Table 2. Amino acid profile of the biomass of Sabella spallanzanii and Microcosmus squamiger.

\begin{tabular}{|c|c|c|c|}
\hline Amino Acid & Abbreviation & S. spallanzanii & M. squamiger \\
\hline Arginine & Arg & $68.5 \pm 0.33$ & $1.65 \pm 0.01$ \\
\hline Histidine & $\mathrm{His}$ & $0.27 \pm 0.00$ & $0.75 \pm 0.01$ \\
\hline Lysine & Lys & $0.25 \pm 0.00$ & $1.29 \pm 0.02$ \\
\hline Threonine & Thr & $0.69 \pm 0.00$ & $1.31 \pm 0.02$ \\
\hline Isoleucine & Ile & $0.12 \pm 0.00$ & $0.17 \pm 0.00$ \\
\hline Leucine & Leu & $0.20 \pm 0.00$ & $0.27 \pm 0.00$ \\
\hline Valine & Val & $0.21 \pm 0.01$ & $0.73 \pm 0.00$ \\
\hline Tryptophan & $\operatorname{Trp}$ & $0.03 \pm 0.00$ & $0.23 \pm 0.00$ \\
\hline Methionine & Met & $0.19 \pm 0.00$ & $0.85 \pm 0.01$ \\
\hline Phenylalanine & Phe & $0.19 \pm 0.00$ & $0.25 \pm 0.00$ \\
\hline Cysteine & Cys & $0.08 \pm 0.00$ & $0.15 \pm 0.00$ \\
\hline Tyrosine & Tyr & $0.14 \pm 0.00$ & $0.33 \pm 0.00$ \\
\hline Aspartic acid & Asp & $1.39 \pm 0.01$ & $0.92 \pm 0.03$ \\
\hline Asparagine & Asn & $0.61 \pm 0.01$ & $0.67 \pm 0.01$ \\
\hline Glutamic acid & Glu & $2.02 \pm 0.02$ & $2.41 \pm 0.05$ \\
\hline Glutamine & Gln & $1.71 \pm 0.01$ & $0.88 \pm 0.00$ \\
\hline Alanine & Ala & $1.06 \pm 0.00$ & $2.94 \pm 0.03$ \\
\hline Glycine & Gly & $49.3 \pm 0.16$ & $1.72 \pm 0.03$ \\
\hline Proline & Pro & $1.14 \pm 0.03$ & $5.15 \pm 0.06$ \\
\hline Serine & Ser & $0.62 \pm 0.00$ & $0.82 \pm 0.01$ \\
\hline Taurine & Tau & $2.30 \pm 0.07$ & $26.6 \pm 0.46$ \\
\hline Ornithine & Orn & $0.19 \pm 0.00$ & $0.65 \pm 0.01$ \\
\hline gamma-Amino-n-butyric acid & GABA & $0.13 \pm 0.00$ & $0.45 \pm 0.01$ \\
\hline Hydroxyproline & HPro & $0.18 \pm 0.00$ & $0.95 \pm 0.00$ \\
\hline beta-Alanine & B-Ala & $0.14 \pm 0.00$ & $0.23 \pm 0.00$ \\
\hline TOTAL & & $131.76 \pm 0.66$ & $52.42 \pm 0.78$ \\
\hline
\end{tabular}




\subsection{Minerals}

The mineral content of S. spallanzanii and M. squamiger is summarized in Table 3. The most abundant macroelements in S. spallanzanii were sodium $(\mathrm{Na}, 18.65 \mathrm{mg} / \mathrm{g}, \mathrm{dw})$, calcium $(\mathrm{Ca}, 17.09 \mathrm{mg} / \mathrm{g}, \mathrm{dw})$, and potassium $(\mathrm{K}, 15.14 \mathrm{mg} / \mathrm{g}, \mathrm{dw})$, while the most abundant microelements in this species were aluminium $(\mathrm{Al}, 13.10 \mathrm{mg} / \mathrm{g}$, $\mathrm{dw})$, iron $(\mathrm{Fe}, 12.12 \mathrm{mg} / \mathrm{kg}$, $\mathrm{dw}$ ) and vanadium (V, $11.6 \mathrm{mg} / \mathrm{kg}, \mathrm{dw})$. In M. squamiger, the dominant macroelements were $\mathrm{Na}(36.24 \mathrm{mg} / \mathrm{g}, \mathrm{dw}), \mathrm{Ca}(14.29 \mathrm{mg} / \mathrm{g}, \mathrm{dw})$ and $\mathrm{K}(11.88 \mathrm{mg} / \mathrm{g}$, dw), and the most abundant microelements were $\mathrm{V}(4.63 \mathrm{mg} / \mathrm{g}, \mathrm{dw}), \mathrm{Al}(4.60 \mathrm{mg} / \mathrm{g}$, dw) and iron $(\mathrm{Fe}, 4.42 \mathrm{mg} / \mathrm{g}, \mathrm{dw})$. Thorium (Th) was detected in trace amounts (S. spallanzanii, $0.28 \mathrm{mg} / \mathrm{g}, \mathrm{dw}$; M. squamiger, $0.48 \mathrm{mg} / \mathrm{g}$, dw).

Table 3. Mineral content of Sabella spallanzanii and Microcosmus squamiger.

\begin{tabular}{|c|c|c|c|}
\hline Mineral & Symbol & S. spallanzanii & M. squamiger \\
\hline \multicolumn{4}{|l|}{ Macroelements } \\
\hline Sodium & $\mathrm{Na}$ & $18.65 \pm 0.26$ & $36.24 \pm 0.64$ \\
\hline Calcium & $\mathrm{Ca}$ & $17.09 \pm 0.38$ & $14.29 \pm 1.11$ \\
\hline Potassium & $\mathrm{K}$ & $15.14 \pm 0.10$ & $11.88 \pm 0.36$ \\
\hline Magnesium & $\mathrm{Mg}$ & $6.66 \pm 0.05$ & $6.75 \pm 0.14$ \\
\hline Phosphorus & $\mathrm{P}$ & $3.97 \pm 0.01$ & $2.66 \pm 0.15$ \\
\hline \multicolumn{4}{|l|}{ Microelements } \\
\hline Iron & $\mathrm{Fe}$ & $12.12 \pm 0.17$ & $4.42 \pm 0.30$ \\
\hline Selenium & Se & nd & nd \\
\hline Manganese & $\mathrm{Mn}$ & nd & $0.41 \pm 0.02$ \\
\hline Molybdenum & Mo & nd & nd \\
\hline Aluminum & $\mathrm{Al}$ & $13.10 \pm 0.27$ & $4.60 \pm 0.17$ \\
\hline Lithium & $\mathrm{Li}$ & nd & nd \\
\hline Vanadium & $\mathrm{V}$ & $11.6 \pm 0.43$ & $4.63 \pm 0.17$ \\
\hline \multicolumn{4}{|l|}{ Toxic elements } \\
\hline Chromium & $\mathrm{Cr}$ & nd & nd \\
\hline Copper & $\mathrm{Cu}$ & nd. & nd \\
\hline Zinc & $\mathrm{Zn}$ & nd & nd \\
\hline Cadmium & $\mathrm{Cd}$ & nd & nd \\
\hline Nickel & $\mathrm{Ni}$ & nd & nd \\
\hline Lead & $\mathrm{Pb}$ & nd & nd \\
\hline Mercury & $\mathrm{Hg}$ & nd & nd \\
\hline Thorium & Th & $0.28 \pm 0.07$ & $0.48 \pm 0.05$ \\
\hline TOTAL & & 98.61 & 86.36 \\
\hline
\end{tabular}

Data represents the mean \pm standard error of mean (SEM) $(n=3)$ and values are expressed as mg/g dry weight (dw). nd: not detected.

\subsection{Chemical Profile of S. spallanzanii and M. squamiger Extracts}

3.4.1. FA

Free FA qualitative and quantitative profiles of methanol and dichloromethane extracts obtained from M. squamiger and S. spallanzanii were achieved by GC-FID, after saponification and derivatization to their respective methyl esters; results are summarized in Table 4 and Figure 2. Thirty free fatty acids, containing between 11 and 24 carbon atoms, with different degrees of unsaturation, were identified in both species (Table 4). The quantification revealed a total FA concentration ranging from $19.09 \mu \mathrm{g} / \mathrm{mg}$ to $459.25 \mu \mathrm{g} / \mathrm{mg}$ (dw). The highest FA amounts were found in S. spallanzanii dichloromethane extract. The FA profiles were strongly influenced by the type of extract. Total FA content was considerably higher in S. spallanzanii and M. squamiger dichloromethane extracts than those of methanolic extracts (459.25 and $251.34 \mu \mathrm{g} / \mathrm{mg}$ against 21.56 and $20.09 \mu \mathrm{g} / \mathrm{mg}(\mathrm{dw})$, respectively). Although their absolute FA content was much lower than that found in dichloromethane extracts, methanol extracts of both species showed a higher content of saturated FA than unsaturated ones. Palmitic acid $\left(\mathrm{C}_{16: 0}\right)(9)$ was the major fatty acid in S. spallanzanii and M. squamiger methanol extracts (accounting for 24.2 and $33.1 \%$ of total fatty acids) and the most representative saturated FA in S. spallanzanii and M. squamiger dichloromethane 
extracts representing ca. 19.5 and $33.1 \%$ of total FA. On the contrary, almost $70 \%$ of the total content of FA found in dichloromethane extracts are unsaturated, distributed by more than $20 \%$ monosaturated FA (MUFA) and almost $50 \%$ polyunsaturated FA (PUFA). cis-9-hexadecenoic acid $\left(\mathrm{C}_{16: 1 n-7 \mathrm{c}}\right)(8)$ and trans-9-octadecenoic acid $\left(\mathrm{C}_{18: 1 n-9 \mathrm{t}}\right)(15)$ were the more representative MUFA in both extracts. The main PUFA detected were $C_{18}$ and $C_{20}$ FA and the concentrations of $C_{20}$ PUFA were higher than those of $C_{18}$ PUFA. cis-5,8,11,14,17Eicosapentaenoic $\left(C_{20: 5 n-3 c}\right)$ (EPA) (18) and cis-8,11,14-eicosatrienoic $\left(C_{20: 3 n-6 c}\right)(19)$ acids, $n-3$ and $n-6$ series, respectively, were the major compounds found in M. squamiger and S. spallanzanii dichloromethane extracts, accounting for 22.4 and $27.2 \%$ of total FA, respectively. In addition of EPA (18), considerable amounts of cis-4,7,10,13,16,19-docosahexaenoic acid $\left(\mathrm{C}_{22: 6 n-3 \mathrm{c}}\right)$ (DHA) was observed in dichloromethane extracts, representing ca. 15 and $5 \%$ of total FA in M. squamiger and S. spallanzanii, respectively.

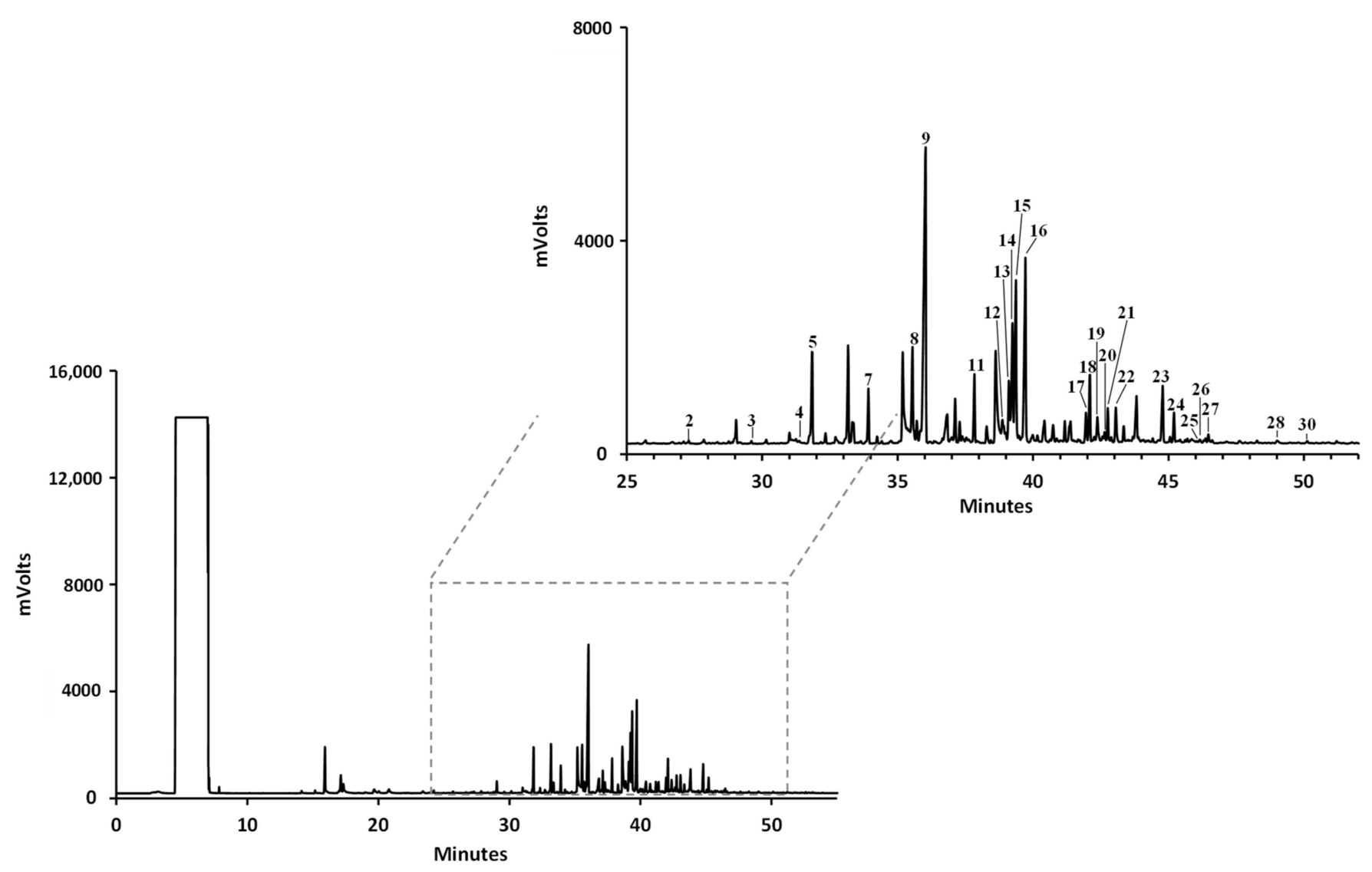

Figure 2. Representative GC-FID chromatogram of the fatty acid profile of Microcosmus squamiger methanol extract. (1) Undecylic acid $\left(\mathrm{C}_{11: 0}\right) ;(2)$ lauric acid $\left(\mathrm{C}_{12: 0}\right) ;(3)$ tridecyclic acid $\left(\mathrm{C}_{13: 0}\right) ;(4)$ myristoleic acid $\left(\mathrm{C}_{14: 1 n-5 \mathrm{c}}\right)$; (5) myristic acid $\left(\mathrm{C}_{14: 0}\right) ;(6)$ cis-10-pentadecenoic acid $\left(\mathrm{C}_{15: 1 n-5 \mathrm{c}}\right) ;(7)$ pentadecyclic acid $\left(\mathrm{C}_{15: 0}\right) ;(8)$ palmitoleic acid $\left(\mathrm{C}_{16: 1 n-7 \mathrm{c}}\right)$; (9) palmitic acid $\left(C_{16: 0}\right) ;(10)$ cis-10-heptadecenoic acid $\left(C_{17: 1 n-7 c}\right) ;(11)$ margaric acid $\left(C_{17: 0}\right) ;(12) \gamma$-linolenic acid $\left(C_{18: 3 n-6 c}\right) ;(13)$ linoleic acid $\left(\mathrm{C}_{18: 2 n-6 \mathrm{c}}\right) ;(14)$ oleic acid $\left(\mathrm{C}_{18: 1 n-9 \mathrm{c}}\right) ;(15)$ elaidic acid $\left(\mathrm{C}_{18: 1 n-9 \mathrm{t}}\right) ;(16)$ stearic acid $\left(\mathrm{C}_{18: 0}\right) ;(17)$ arachidonic acid $\left(\mathrm{C}_{20: 4 n-6 \mathrm{c}}\right)$; (18) eicosapentaenoic acid $\left(C_{20: 5 n-3 c}\right) ;(19)$ homo- $\gamma$-linolenic acid $\left(C_{20: 3 n-6 c}\right) ;(20)$ eicosadienoic acid $\left(C_{20: 2 n-6 c}\right) ;(21) \alpha$-linolenic acid $\left(\mathrm{C}_{18: 3 n-3 \mathrm{c}}\right) ;(22)$ arachidic acid $\left(\mathrm{C}_{20: 0}\right) ;(23)$ heneicosylic acid $\left(\mathrm{C}_{21: 0}\right) ;(24)$ docosahexaenoic acid $\left(\mathrm{C}_{22: 6 n-3 \mathrm{c}}\right)$; (25) linoelaidic acid $\left(C_{18: 2 n-6 t}\right) ;(26)$ erucic acid $\left(C_{22: 1 n-9 c}\right) ;(27)$ behenic acid $\left(C_{22: 0}\right) ;(28)$ tricosylic acid $\left(C_{23: 0}\right) ;(29)$ nervonic acid $\left(C_{24: 1 n-9 c}\right)$; (30) lignoceric acid $\left(\mathrm{C}_{24: 0}\right)$. 
Table 4. Fatty acid content of Sabella spallanzanii and Microcosmus squamiger extracts ( $\mu \mathrm{g} / \mathrm{mg}$ dry extract, $\mathrm{dw})^{1}$.

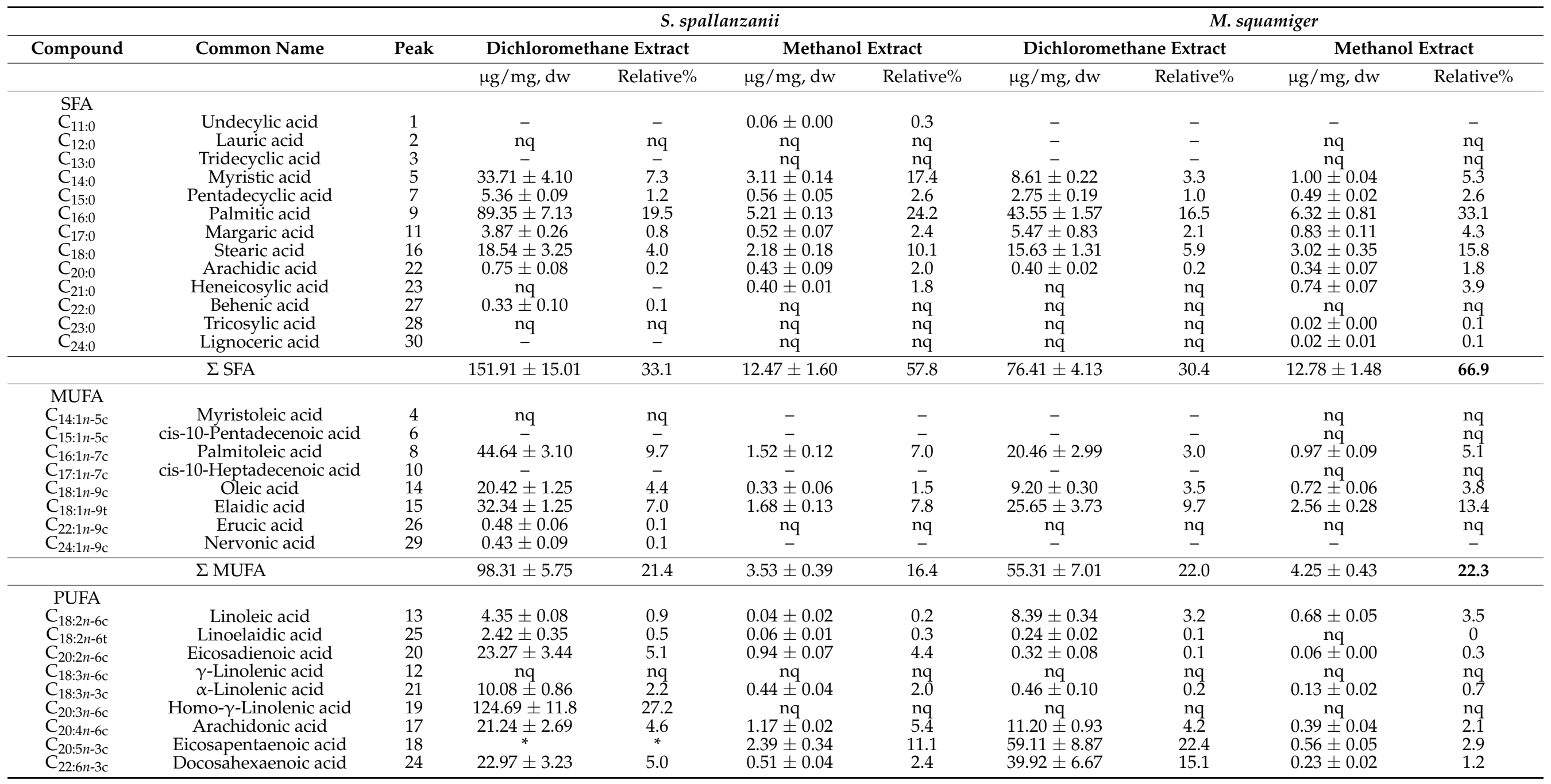


Table 4. Cont.

\begin{tabular}{|c|c|c|c|c|c|c|c|c|c|c|}
\hline \multirow{3}{*}{ Compound } & \multirow{3}{*}{$\begin{array}{l}\text { Common Name } \\
\Sigma \text { PUFA }\end{array}$} & \multirow{3}{*}{ Peak } & \multicolumn{4}{|c|}{ S. spallanzanii } & \multicolumn{4}{|c|}{ M. squamiger } \\
\hline & & & \multicolumn{2}{|c|}{ Dichloromethane Extract } & \multicolumn{2}{|c|}{ Methanol Extract } & \multicolumn{2}{|c|}{ Dichloromethane Extract } & \multicolumn{2}{|c|}{ Methanol Extract } \\
\hline & & & $209.03 \pm 22.45$ & 45.5 & $5.56 \pm 0.69$ & 25.8 & $119.64 \pm 17.01$ & 47.6 & $2.05 \pm 0.18$ & 10.7 \\
\hline$\sum n-3$ & & & $33.05 \pm 4.09$ & 7.2 & $3.34 \pm 0.58$ & 15.5 & $99.48 \pm 5.64$ & 39.6 & $0.92 \pm 0.09$ & 4.8 \\
\hline$\sum n-6$ & & & $175.98 \pm 18.36$ & 38.2 & $2.22 \pm 0.11$ & 10.3 & $20.16 \pm 1.37$ & 8.0 & $1.13 \pm 0.09$ & 5.9 \\
\hline$\sum n-7$ & & & $44.64 \pm 3.1$ & 9.7 & $1.52 \pm 0.12$ & 7.0 & $20.46 \pm 2.99$ & 8.1 & $0.97 \pm 0.09$ & 5.1 \\
\hline$\sum n-9$ & & & 53.67 & 11.7 & $2.01 \pm 0.27$ & 9.3 & $34.85 \pm 4.02$ & 13.9 & $3.29 \pm 0.34$ & 17.2 \\
\hline$n-6 / n-3$ & & & 5.33 & & 0.67 & & 0.20 & & 1.23 & \\
\hline & TOTAL & & $459.25 \pm 43.20$ & 100.0 & $21.56 \pm 2.68$ & 100.0 & $251.34 \pm 28.15$ & 100.0 & $19.09 \pm 2.09$ & 100.0 \\
\hline
\end{tabular}

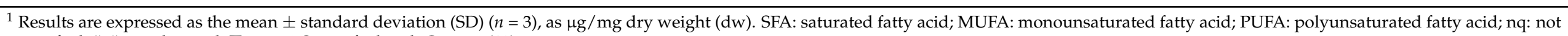
quantified; “-“: not detected; $\sum$ sum. * Quantified with $C_{20: 3 n-6 c}(19)$. 


\subsubsection{Carotenoids}

The carotenoid composition of the extracts is depicted in Table 5 and Figure 3. Six xanthophylls were identified in M. squamiger dichloromethane extract; however, no carotenoids were detected in the M. squamiger methanolic extract, nor in the $S$. spallanzanii extracts (dichloromethane and methanolic). In addition to fucoxanthinol (1), two other fucoxanthinrelated compounds ( $a$ and $b$ ) were found in M. squamiger dichloromethane extract; however, their identification was not achieved. Additionally, the presence of three carotenes whose identity could not be defined was observed. The injection of $\alpha$-carotene, $\beta$-carotene, $\varepsilon$ carotene, and $\gamma$-carotene, at same chromatographic conditions, allows us to ensure that it is none of these compounds. Fucoxanthinol (1) and fucoxanthin (2) were the major compounds.

Table 5. Carotenoid content of Sabella spallanzanii and Microcosmus squamiger extracts $(\mu \mathrm{g} / \mathrm{g} \text { dry extract })^{1}$.

\begin{tabular}{cccccc}
\hline \multirow{2}{*}{ Peak } & \multirow{2}{*}{ Compound } & \multicolumn{2}{c}{ M. squamiger } & \multicolumn{2}{c}{ S. spallanzanii } \\
\cline { 3 - 6 } & & Dicloromethane Extract & Methanol Extract & Dicloromethane Extract & Methanol Extract \\
\hline 1 & Fucoxanthinol & $2.51 \pm 0.28$ & nd & nd & nd \\
2 & Fucoxanthin & $1.66 \pm 0.06$ & nd & nd & nd \\
3 & Anteraxanthin & nq & nd & nd & nd \\
4 & Astaxanthin & $0.03 \pm 0.00$ & nd & nd & nd \\
5 & Lutein & $0.14 \pm 0.01$ & nd & nd & nd \\
6 & Zeaxanthin & nq & - & - & - \\
& TOTAL & $4.34 \pm 0.35$ & & & \\
\hline
\end{tabular}

${ }^{1}$ Results are expressed as the mean \pm standard deviation (SD) ( $\left.n=3\right)$, as $\mu \mathrm{g} / \mathrm{g}$ dry weight (dw). nq: not quantified; nd: not detected. Peaks refers to the HPLC-DAD profile depicted in Figure 3.

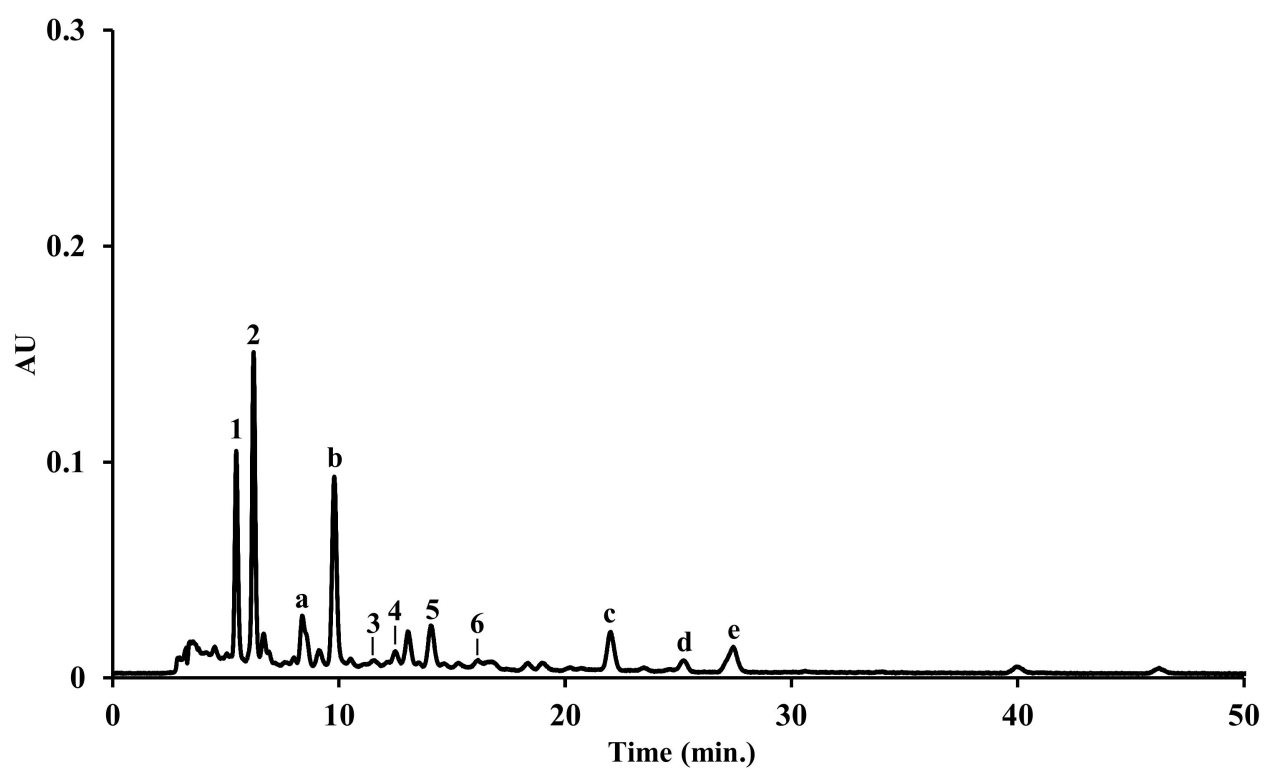

Figure 3. HPLC-DAD carotenoid profile of the dichloromethane extract from Microcosmus squamiger. Identity of compounds as in Table 5.

\subsection{Antioxidant Properties of the Extracts}

In this work, dichloromethane and methanol extracts from S. spallanzanii and M. squamiger were evaluated for the first time for antioxidant properties, by four complementary in vitro methods, targeting free radicals and redox metals, namely copper $(\mathrm{Cu})$ and iron $(\mathrm{Fe})$, and results are summarized in Table 6. In S. spallanzanii, the extraction yields for dichloromethane and methanol extracts were 5.06 and $6.32 \%$, respectively, and the $\mathrm{IC}_{50}$ values were not reached at the maximum concentration tested $(10 \mathrm{mg} / \mathrm{mL})$ for the dichloromethane extract. However, the methanol extract of $S$. spallanzanii exhibited metal chelating properties 
towards both metals with $\mathrm{IC}_{50}$ values of $1.7 \mathrm{mg} / \mathrm{mL}$ and $4.1 \mathrm{mg} / \mathrm{mL}$ for $\mathrm{Cu}$ and $\mathrm{Fe}$, respectively. In M. squamiger, the extraction yields for dichloromethane and methanol extracts were 2.42 and $15.6 \%$, respectively, and, similar to observations in S. spallanzanii, the application of the dichloromethane extract did not allow us to reach the $\mathrm{IC}_{50}$ values, up to $10 \mathrm{mg} / \mathrm{mL}$, in all the assays. However, the methanol extract was able to chelate $\mathrm{Cu}$ ions, with an $\mathrm{IC}_{50}$ value of $7.6 \mathrm{mg} / \mathrm{mL}$.

Table 6. Extraction yields (\%), DPPH radical scavenging activity and metal chelating activities on iron (ICA) and copper (CCA) $\left(\mathrm{IC}_{50}, \mathrm{mg} / \mathrm{mL}\right)$ of dichloromethane and methanol extracts of Sabella spallanzanii and Microcosmus squamiger.

\begin{tabular}{cccccc}
\hline Samples & Extract & Yield (\%) & DPPH & ICA & CCA \\
\hline \multirow{2}{*}{ S. spallanzanii } & Dichloromethane & 5.06 & $\mathrm{nr}$ & $\mathrm{nr}$ & $\mathrm{nr}$ \\
& Methanol & 6.32 & $\mathrm{nr}$ & $4.1 \pm 0.1^{\mathrm{b}}$ & $1.7 \pm 0.0^{\mathrm{c}}$ \\
M. squamiger & Dichloromethane & 2.42 & $\mathrm{nr}$ & $\mathrm{nr}$ & $>1 \mathrm{nr}$ \\
BHA * $_{\text {EDTA * }}$ & Methanol & 15.65 & $\mathrm{nr}$ & $\mathrm{nr}$ & $7.6 \pm 0.2^{\mathrm{b}}$ \\
\hline
\end{tabular}

Data represents the mean \pm standard error of mean (SEM) $(n=6)$. In the same column, values followed by different letters are significantly different at $p<0.05$ (one-way ANOVA with Tukey post hoc test); nr: $\mathrm{IC}_{50}$ value not reached; * positive control; BHA: butylated hydroxyanisole; EDTA: ethylenediaminetetraacetic acid.

All samples showed antioxidant activity in the ORAC assay (Figure 4). Regarding S. spallanzanii, the methanol extract had a higher activity $(23.3 \pm 3.1 \mathrm{mg} \mathrm{TE} / \mathrm{g}$ extract) than the dichloromethane extract ( $14.0 \pm 3.0 \mathrm{mg}$ TE/g extract). In M. squamiger, similar ORAC values were obtained for the methanol $(23.0 \pm 4.9 \mathrm{mg} \mathrm{TE} / \mathrm{g})$ and dichloromethane extract $(26.3 \pm 7.3 \mathrm{mg} \mathrm{TE} / \mathrm{g})$.

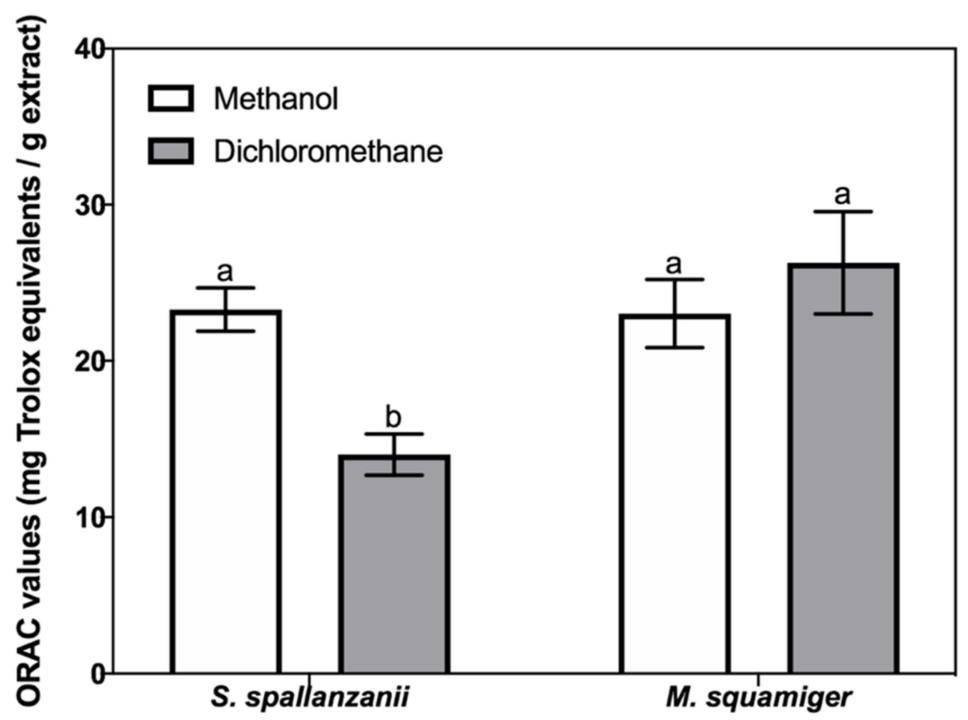

Figure 4. Antioxidant activity (mg trolox equivalents TE/g) determined by the oxygen radical absorbance capacity (ORAC) assays in dichloromethane and methanol extracts of Sabella spallanzanii and Microcosmus squamiger. For the same species, collumns labelled with different letters re significantly different $(p<0.05)$.

\section{Discussion}

Blue Biotechnology is considered by the European Union (EU) as one of the bases for the blue growth agenda, which aims to guarantee the sustainable use of marine resources [36]; efforts are being applied to identify new marine species as sources of products with commercial applications, such as medical drugs, foodstuffs, feed, and cosmetics [37-41]. The identification of such uses for invasive species could contribute for their 
sustainable use and control [27-29,42]. This work focused on the biochemical properties of S. spallanzanii and M. squamiger, aiming for their biotechnological valorisation. Both species are invasive and can co-exist in their habitat. Sabella spallanzanii belongs to the Polychaeta group, the major among Annelida, occupying almost every area of the marine environment [39]. Despite its abundance and ecological relevance, research on the biotechnological uses of marine Polychaeta is more recent than those focusing on terrestrial or continental water annelids [39]. Microcosmus squamiger is an Ascidian, a group of marine invertebrates considered an important source of secondary metabolites with important biological properties, such as anti-fouling and anti-tumoral [43].

Aiming to gain an insight into the nutritional properties of both species, samples were profiled for proximate composition, specifically moisture, ash, protein, lipids, and energetic value. The moisture level of $S$. spallanzanii was lower than the value reported for the same species collected in the Southern Adriatic Sea, Italy (79.3\%) [6], which may be related with the fact that, in the latter study, the leathery tube was removed before analysis. The moisture content of $M$. squamiger was similar to the value reported for the same species collected in the Palk Bay region, Southeast coast of India [23]. Recent studies have shown the potential of marine invertebrates, including annelid worm and tunicates, as potential sources of alternative fish meal in view of the current trend in aquaculture expansion and the consequent growing need to identify new sources for fish feed ingredients $[6,20,44]$. Therefore, one of the possible uses of biomass from S. spallanzanii and M. squamiger could be as ingredients in fish meal. The moisture content is important when considering ingredient storage and in the feed manufacturing process, such as extrusion; however, it does not necessarily negatively impact the final moisture content of the feed [45]. The ash levels of S. spallanzanii and M. squamiger were higher than those reported for the same species [6,24], which may be related to the fact that, in the present work, the whole organisms were analysed, while previous studies evaluated only muscle samples. High ash levels have implications in fish feed: a fish meal with a high ash content usually results in a faster transit rate, which leads to increased growth feed intake and growth, but also to poor feed efficiency [46].

When considering the nutritional value of a species for use in animal nutrition, macronutrients such as proteins and lipids are the most important ingredients [47], since they are essential for maintaining growth, reproduction, and physiological functions of the target animals [48]. A high-quality fish meal should contain up to $72 \%$ of protein by weight [49]. The high protein level of $S$. spallanzanii determined in this work is lower than the value reported for the same species $(54.8 \%, \mathrm{dw})$ [6], while the M. squamiger protein content was higher than that reported for the same species [24]. Determined levels are lower than the recommended protein contents of fish meals, but higher than those reported for some edible marine invertebrates, such as mussel (Mytilus sp., 37.9\%) and Japanese sea cucumber (Stichopus japonicus Selenka, 1867, (4.74\%) [50,51], thus suggesting its potential as a protein source for human consumption. Moreover, protein from marine invertebrates exhibit an array of highly relevant biological properties, including anticancer, antioxidant and tissue regeneration assets, and, therefore, are highly valued by the nutraceutical and biomedical industries [40]. Both species had low crude fat levels, which is in accordance with previous results in S. spallanzanii (8\% with seasonal variation) [6] and M. squamiger [24]. Low crude fat is common in different marine invertebrates, as, for example, the polychaete Nereis diversicolor (O.F. Müller, 1776) [25], and several ascidian species collected from the southeast coast of India [23]. Such fat levels correspond to fatty and semi fat fish and are lower to the total lipids commonly present in commercial fish feed (10-25\%) [48]. The calculated gross energy for $S$. spallanzanii was lower than the results reported for the same species $(4.8 \mathrm{kcal} / \mathrm{g}$, corresponding to $20.4 \mathrm{MJ} / \mathrm{kg}$ [6].

Amino acids (AAs) are the basic building blocks of proteins and play an essential role in basic physiological performance by intervening in the bioavailability of nutrients and gene expression. The level of total free amino acids was higher in S. spallanzanii, and, in this species, the most abundant amino acid was arginine, which is consistent with the 
findings of Stabili et al. [6], in the same species, and similar to values reported for several foods, including beef [52]. Arginine is an essential AA to humans and can be provided by lean meats, nuts, seeds, and leguminous. It plays a major role in protein synthesis, improves endothelial and immune function, and reduces oxidative stress and vasodilation by increasing the production of nitric oxide (NO) [53,54]. Arginine has an important role in vascular function and skeletal muscle maintenance and is a popular nutritional supplement since it has beneficial effects on athletic performance and health in general [55]. The intake of glycine is also linked with a reduction of total cholesterol levels in serum [56]. The predominance of arginine is especially relevant when considering the use of $S$. spallanzanii as a fish meal ingredient, because arginine is an indispensable amino acid required by all fish species [57]. For example, a deficiency of arginine in diet resulted in reduced growth and low feed efficiency in Japanese flounder (Paralichthys olivaceus Temminck \& Schlegel, 1846), milkfish (Chanos chanos Forsskål, 1775) and Atlantic salmon (Salmo salar Linnaeus, 1758) [58-60]. In channel catfish (Ictalurus punctatus Rafinesque, 1818), high mortality and fin erosion were reported because of arginine deficiency [61]. Besides, glycine is the major constituent of collagen and elastin [62]. Collagen is responsible for the strength, rigidity, and flexibility of connective tissues and is essential for growth, development, and overall animal health [63]. Elastin is also structurally important in connective tissue, thus giving the elastic properties to vertebrate organs and tissues [64].

The second most abundant amino acid in S. spallanzanii was glycine, which can be synthesized by the animals through interconvertion from serine in the liver and kidneys by tetrahydrofolate-dependent hydroxymethyltransferase [65]. However, the energy cost may result in suboptimal growth [39]. Xie et al. [66] showed that dietary supplementation with $0.3 \%$ of glycine enhanced growth rate in juvenile whiteleg shrimp (Litopenaeus vannamei Boone, 1931). Furthermore, a supplementation with $0.5 \%$ of glycine resulted in the improvement of weight gain, antioxidative capacity, and immunity in Nile tilapia (Oreochromis niloticus Linnaeus, 1758) [67]. Besides, the sweet flavour of glycine stimulated the food intake of giant tiger prawn (Penaeus monodon Fabricius, 1798) [68]. Therefore, our results suggest that $S$. spallanzanii could have potential use as a natural attractant, with the potential to replace synthetic compounds, in line with the requirements of the modern trend for organic fish production [6]. Attractants are compounds or ingredients that, when added to the feed, boosts its taste and acceptableness by fish, and are widely used in several sectors of animal production, including aquaculture $[6,69]$. The price of attractants is higher than that of fish meal, and are already used in fish feeds, especially when fish meal is replaced by diets rich in plant-based protein [6].

Taurine was identified as the dominant FAA in $M$. squamiger in higher levels than those reported for important sources of taurine, including cod (Gadus spp.) fillet (120 mg/100 g, $\mathrm{ww})$, saithe (Pollachius virens), and peeled shrimps (220 mg/100 g, ww) [70]. Taurine (a sulfur-containing $\beta$-amino acid) is indicated as a functional feed additive due to its importance for the improvement of fish performance, immunity, and intestinal health [71-73]. The benefits of taurine supplementation are species-specific in relation to the levels in the feed and feeding duration [73]. Gaylord et al. [74] showed that supplementation of taurine improved the growth, feed conversion ratios, protein retention efficiencies and energy retention efficiencies in rainbow trout (O. mykiss). Moreover, the weight gains, feed conversion ratios and protein efficiency ratios of giant tiger prawn (P. monodon) were higher when taurine was included in the fish diet [75]. Taurine deficiency resulted in green liver syndrome and poor growth performance in Japanese amberjack (Seriola quinqueradiata Temminck \& Schlegel, 1845) and red seabream (Pagrus major Temminck \& Schlegel, 1843) [76,77]. The ability to synthetise taurine was detected in some species, such as Japanese flounder (P. olivaceus) and rainbow trout (O. mykiss); however, it was not observed in others, as, for example, Japanese amberjack (S. quinqueradiata), Atlantic bluefin tuna (Thunnus thymus Lineu, 1758) and skipjack tuna (Katsuwonus pelamis Linnaeus 1758) [78]. When the endogenous fish production is absent or insufficient to meet the physiological needs, taurine supplementation is required to avoid deficiency [79]. It should be mentioned that 
alternative protein sources for fishmeal, such as soybean meal, contain very low taurine levels [65]. Supplementation of synthetic taurine in fish diets is allowed in Europe [80]. However, in the USA, taurine supplementation is only allowed if it is added indirectly to the fishmeal through a feed ingredient naturally rich in that element [79].

Moreover, taurine is a physiologically essential nutrient for humans, especially infants and children, and plays major roles in human physiology and nutrition, including the facilitation of intestinal absorption of dietary lipids and cholesterol elimination, stabilization of cell membranes, besides exhibiting antioxidant and anti-inflammatory properties, among others $[81,82]$. Humans have a very low ability to synthesize taurine, when compared to other animals (e.g., livestock and poultry), and it is abundant in animal-source foods (such as beef) but almost absent in plants [83,84]. Therefore, vegetarians and vegans are at increased risk for taurine deficiency since the precursors for taurine synthesis (methionine and cysteine) are present at low levels in most proteins of plant origin [82]. Taurine has been used for 45 years as a dietary supplement to improve health in humans and animal models of metabolic syndrome [82,85]. The use of taurine supplementation is especially important in type-2 diabetic patients, since they exhibit a $25 \%$ lower concentration of taurine in plasma than normal subjects [86]. Moreover, recent research has shown that it has a protective effect against various xenobiotics, mainly due to its anti-oxidative, anti-inflammatory, and membrane-stabilizing properties, and is regarded as a promising dietary supplement for the treatment of liver diseases [87]. Besides its importance to humans, taurine supplementation is also highly relevant in veterinary practice. For example, taurine is not an essential amino acid in dogs, since taurine precursors (cysteine and methionine) are used by the liver and the central nervous system to synthesize taurine. However, taurine supplementation can revert dilated cardiomyopathy, a common dog disease, since it is linked to reduced plasma taurine levels [88-91]. Overall, our results suggest $M$. squamiger as a source of taurine for human and veterinary uses, and of fishmeal taurine-rich ingredients.

Minerals have key metabolic roles in all organisms and are therefore important ingredients in formulations used in different commercial areas, for example, as food and feed ingredients. The most abundant minerals in S. spallanzanii and M. squamiger were $\mathrm{Na}, \mathrm{Ca}$, and $\mathrm{K}$. The $\mathrm{Na}$ and Ca levels of $\mathrm{S}$. spallanzanii were lower than those detected in the same species, by other authors [6]. Besides being a structural constituent of bones, exoskeleton, teeth and scales, $\mathrm{Ca}$ is a cofactor for enzymatic processes and is crucial in the conservation of cell membrane integrity, blood clotting, muscle contraction, bone mineralization, adequate nerve impulse transmission and osmoregulation. Seawater contains a significant amount of dissolved $\mathrm{Ca}$, and fish can absorb it from the surrounding water to fulfil their metabolic requirements [92]. The level of $\mathrm{K}$ in S. spallanzanii was higher than the one detected in the same species, collected elsewhere [6]. This element is an essential component of the fish diets since it is crucial for skeletal development and intermediary metabolism [93]; however, since P supplementation in fish feed is an important source of eutrophication, its supplementation must be a balance between the P requirements of fish and the possible environmental impacts. If considering $M$. squamiger biomass as a potential fishmeal ingredient, its Ca levels could be relevant, since several studies have shown that adequate dietary Ca supplementation has beneficial effects on the performance of several fish species, for example, redlip mullet (Liza haemmatocheila Temminck \& Schlegel, 1845) [94].

The most abundant micro elements in S. spallanzanni were aluminium $\mathrm{Al}, \mathrm{Fe}$, and $\mathrm{V}$, while in M. squamiger they were $\mathrm{V}, \mathrm{Al}$, and $\mathrm{Fe}$. The Fe level in S. spallanzanii was higher than the level detected in the same species [6]. Iron is an important micronutrient for teleost fish, is an integral component of proteins, participates in cellular respiration and oxygen transfer, and is routinely added to fish feeds in aquaculture [95]. Vanadium was also detected, although in lower amounts $(0.56 \mathrm{ppm})$ in M. squamiger collected in the southeast coast of India [24]. Ascidians accumulate V in their blood cells, vanadocytes [96], and the toxicity and essentiality of this element are still inconclusive [97]. No toxic elements were detected in both species, except for Th, which was detected in trace amounts. Thorium is a 
radioactive metal with natural occurrence in the Earth's crust, in minerals such as thorite and monazite [98]. Radioactive elements emitting alpha particles are of high concern since they are highly radiotoxic to the body. Thorium has three alpha-emitting radioisotopes: 228Th $\left(\mathrm{T}_{1 / 2}=1.91 \mathrm{y}\right),{ }^{230 \mathrm{Th}}\left(\mathrm{T}_{1 / 2}=7.54 \times 10^{4} \mathrm{y}\right),{ }^{232} \mathrm{Th}\left(\mathrm{T}_{1 / 2}=1.4 \times 10^{10} \mathrm{y}\right)$ [99], has very low water solubility and strongly adsorb onto organic/inorganic particles, being therefore rather unavailable for biological uptakes [100]. Adsorbed Th enters the human body through inhalation or ingestion or through skin wounds and excessive exposure can induce cancer of the liver, lungs, pancreas, spleen, bone, and blood [101]. Th originates from the air and terrestrial sources to the marine environment [102], and was detected in feedstuffs, such as meat-bone meal and fish meal from aquaculture [103], and in molluscs and fish collected from the Southern Baltic Sea [104,105]. However, none of these studies indicated radiation hazards. Therefore, studies should be conducted aiming at the determination of the Th radionuclides $228 \mathrm{Th}, 230 \mathrm{Th}$ and ${ }^{232} \mathrm{Th}$ in S. spallanzanii and M. squamiger, to assess if they pose a radiological hazard.

Sabella spallanzanii was proposed as a potential biofilter in the treatment of wastes from intensive aquaculture due to its high capacity to remove particulate organic matter from the water column [106]. In another work, S. spallanzanii and the green macroalga Chaetomorpha linum (Muller) Kütz. 1849, were cultivated as bioremediators in an integrated multitrophic aquaculture system (IMTA), and obtained biomass was appraised for potential uses [7]. The authors observed a significant increase in the polychaete's biomass, with high protein levels and adequate fatty acids profile, and suggested that it could partially replace the fishmeal for feeding European seabass (Dicentrarchus labrax Linnaeus, 1758) [7]. These results, combined with those obtained in this work, suggest $S$. spallanzanii as a strong candidate to be used in IMTA systems capable to reduce the environmental impact resulting from aquaculture, due to its bioremediation properties, which allow for economic revenues using produced biomass as fish meal ingredient. Similar studies should be conducted targeting $M$. squamiger.

Unravelling lipophilic signatures of S. spallanzanii and M. squamiger may assist the valorisation of these marine invertebrates as non-traditional sources of functional compounds and fish feed ingredients. Within lipid components, FA as part of molecules or acting individually, have diverse functions in cells that range from structural "building blocks" of cell membranes to suppliers of energy and signalling molecules [107,108].

As far as we know, this is the first report about the FA composition of M. squamiger. The overall qualitative FA profiles of $S$. spallanzanii are like those previously described for this polychaete [6,7]. Palmitic acid $\left(\mathrm{C}_{16: 0}\right)(9)$ was the major saturated FA found in S. spallanzanii and M. squamiger methanol and dichloromethane extracts. As previously published studies present relative values of FA, it is not possible to compare the absolute content of compounds and totals of $S$. spallanzanii herein obtained with those of these works. Still, in all previous works, palmitic acid $\left(\mathrm{C}_{16: 0}\right)(9)$ was reported as the predominant FA in this species [6,7].

The high content of dihomo- $\gamma$-linolenic acid $\left(\mathrm{C}_{20: 3 n-6 c}\right)$, EPA $\left(\mathrm{C}_{20: 5 n-3 c}\right)$ and DHA $\left(\mathrm{C}_{22: 6 n-3 \mathrm{c}}\right)$ in dichloromethane extracts of both species open doors for the potential use of these organisms as alternative sources of essential PUFAs for fish feed. The $n-3$ PUFA EPA and DHA are usually included as ingredients in formulations of fish feeds, to ensure adequate fish growth and health, and to improve fish quality for their consumers [109]; however, due to resource depletion, its cost is on the rise [7]. A distinct relative content of n-3 and n-6 PUFAs were observed in M. squamiger and S. spallanzanii dichloromethane extracts. The n-6 PUFAs relative content found herein for $S$. spallanzanii was higher than those reported in previous studies (around 10\%) [7]. An opposite trend was observed in M. squamiger dichloromethane extract characterized by a predominance of $n-3$ PUFA over n-6 PUFA.

The distinct biological properties attributed to these two families of PUFAs, as for example, cardioprotective action and immunomodulatory effects, make the balance between dietary n-6 and n-3 fatty acids an important consideration from a human health 
perspective $[109,110]$. Indeed, regarding the relationship between $n-3$ and $n-6$ fatty acids, inflammation and disease pathogenesis continue to be subjects of extensive study. While several studies suggest that biological effects of $n-3$ and $n-6$ PUFAs depend on the maintenance of a proper balance between the two series of FA, rather than on the absolute amount of each's single compound [111], other authors consider that the absolute mass of essential FA consumed, rather than their $n-6 / n-3$ ratio, should be the main consideration when contemplating lifelong dietary habits affecting health benefits from their intake [109]. In fact, $n-6$ and $n-3$ PUFAs are precursors of potent lipid mediators, called eicosanoids, which play an important role in the regulation of inflammation. Eicosanoids derived from $n-6$ PUFAs (for example, arachidonic acid) have pro-inflammatory and immunoactive functions, whereas eicosanoids derived from $n$-3 PUFAs (for instance, eicosapentaenoic acid (EPA) and docosahexaenoic acid (DHA)) have anti-inflammatory properties, traditionally attributed to their ability to inhibit the formation of $n-6$ PUFA-derived eicosanoids [112]. On the other hand, epidemiological and clinical studies have established that the $n-6$ PUFA linoleic acid (13), and the $n-3$ PUFAs, linolenic acid (21), eicosapentaenoic acid (EPA) (18) and docosahexaenoic acid (DHA) (24), collectively protect against coronary heart diseases [109]. Present Western diets are deficient in $n-3$ fatty acids and have excessive amounts of $n-6$ fatty acids compared with the diet on which human beings evolved and established their genetic patterns. The high $n-6 / n-3$ PUFA ratio (of around 15-20:1) currently found in today's Western diets promotes the pathogenesis of many diseases, including cardiovascular disease, inflammatory and autoimmune diseases, and cancer, whereas increased levels of $n$-3 PUFA (a low $n-6 / n-3$ ratio) exert suppressive effects [113]. Very low $n-6 / n-3$ ratios were found herein for $M$. squamiger dichloromethane and methanol extracts, as well as for $S$. spallanzanii methanol extract, which agrees with the previous report by Stabili et al. [7]. A higher $n-6 / n-3$ ratio was found for $S$. spallanzanii dichloromethane extract, yet still below the maximum dietary $n-6 / n-3$ ratio recommended by the World Health Organization $(<10)$ [114]. The results herein obtained showed the potential of these marine invertebrate specimens for nutritional purposes.

Carotenoids are the most common group of pigments in marine settings, such as those observed in the terrestrial environment [115]. They are synthesized by autotrophic marine organisms, such as bacteria, algae, and fungi, while marine animals can directly accumulate them from food or partly modify them through metabolic mechanisms [115]. Carotenoids are vital for marine animals, since they display key photoprotective and antioxidant functions through the dissipation of light energy, and free radical detoxification, especially in shallow habitats characterized by sporadic exposure to excessive solar radiation $[116,117]$. Carotenoids are also important in animals' nutrition due to their roles in provitamin A activity and immunological modulation [117]. No carotenoids were detected in S. spallanzanii, while fucoxanthinol (1) and fucoxanthin (2) were the major compounds in the extracts from M. squamiger. Fucoxanthin is an abundant marine carotenoid in edible brown algae, such as Undaria pinnatifida, Hijikia fusiformis, Saccharina japonica, and Sargassum horneri [118,119], and was also identified in marine invertebrates, as for example the ascidian Botryllus schlosseri (Pallas, 1766) from the Black Sea [120]. Fucoxanthin is considered as one of the most potent carotenoids regarding anti proliferative activity in human cancer cells and exhibited no toxicity in rodent models [121]. Other beneficial health effects of fucoxanthin include regulation of obesity, diabetes, and inflammation [87]. Fucoxanthinol is a major gastrointestinal metabolite of dietary fucoxanthin, and to date, the number of natural sources of this compound is reduced, including, for example, the diatom Nitzschia laevis $[122,123]$. Fucoxanthinol also plays essential roles in the regulation of obesity, and displays relevant health promoting properties, such as antidiabetic, anti-tumoral and anti-inflammatory [124].

Carotenoids have a high demand in the cosmetics, pharmaceutical and food areas, due to their multiple health enhancement properties. In fact, estimated value for the global carotenoid market in 2016 was approximately 1.20 billion USD, which is expected to reach 1.53 billion USD by 2021, at a compound annual growth rate (CAGR) of $3.78 \%$ 
from 2016 to 2021 [125]. They are also often used in aquaculture to reinforce fish colour, which increases the consumer's perception of good quality and organoleptic properties; furthermore, they are considered semi-essential nutrients that promote optimal fish survival and growth at relatively low dietary-inclusion levels, due to their several functions in fish, such as antioxidant, anti-inflammatory, anti-stress, and immunomodulation agents [126]. Therefore, the carotenoid contents of $M$. squamiger could be a high added asset if considering the use of this species as a source of bioactive fish meal ingredient.

In this work, S. spallanzanii and M. squamiger were evaluated for the first time for antioxidant properties, by in vitro methods, targeting free radicals and redox metals, namely $\mathrm{Cu}$ and $\mathrm{Fe}$. The methanol extract of $S$. spallanzanii exhibited metal chelating properties towards both metals, while the methanol extract from M. squamiger was able to chelate $\mathrm{Cu}$ ions. Iron and $\mathrm{Cu}$ are essential elements for fish metabolism; however, their excess can induce oxidative stress in aquatic organisms by promoting the formation of reactive oxygen species (ROS) that may cause oxidative damage to proteins and lipids, which is deleterious to the overall fish health, fish quality and suitability for human consumption $[127,128]$. Metal chelators, such as EDTA, are used in aquaculture to counteract metal accumulation. For example, dietary EDTA supplementation in Nile tilapia (O. niloticus) was used and its benefits were attributed to the enhancement of the antioxidant activity and reduction of heavy metal bioaccumulation in fish [129].

All samples showed antioxidant activity in the ORAC assay, and the obtained values were lower than those obtained with extracts from other marine invertebrates, such as the Atlantic sea cucumber (Cucumaria frondosa (Gunnerus 1767) (values ranging between 35 and $200 \mathrm{mg} \mathrm{TE} / \mathrm{g}$ ) [130]. In aquaculture, oxidative stress leads to damages in biomolecules, causing immune suppression, pathological symptoms, and slow growth in fish; it results from several factors, such as high temperature and hypoxia [131]. Synthetic antioxidants such as ethoxyquin have been widely included in fish feed to counteract oxidative stress and promote fish health, and to improve the feed quality and shelf life [132]. However, the uncertainty of the health implication of synthetic antioxidants implies the need for efficient and cost effective alternative natural sources [132]. Our results suggests that $S$. spallanzanii and M. squamiger contain polar molecules with metal chelation and antioxidant properties, and, therefore, could be explored as sources of ingredients in fishmeal, as natural metal chelators and to counteract oxidative stress. These results, combined with those previously reported in this work, suggest both species as sources of ingredients with high added value to be used for different commercial purposes, and raise the interest in using biomass from both species collected from the wild, to control its populations, or to produce them by sustainable methods. As stated previously, S. spallanzanii can be successfully produced by IMTA [7]; however, there are no reports on the production of $M$. squamiger. There are, however, reports of the breeding of other ascidians, such as the tunicate Botrylloides diegensis Ritter \& Forsyth, 1917, in recirculating artificial seawater conditions [133].

\section{Conclusions}

Our results indicate that S. spallanzanii contains appreciable levels of ash and protein, a predominance of the amino acids arginine and glycine, of the minerals $\mathrm{Na}, \mathrm{Ca}$, and $\mathrm{K}$, and of the FA dihomo- $\gamma$-linolenic, palmitoleic and palmitic acids The methanol extract of $S$. spallanzanii exhibited $\mathrm{Cu}$ and Fe chelating properties, and capacity to scavenge peroxyl free radicals. Microcosmus squamiger had high total protein levels, was enriched in the amino acid taurine, in the minerals $\mathrm{Na}, \mathrm{Ca}$ and $\mathrm{K}$, and in the FA eicosapentaenoic, docosahexaenoic, elaidic and palmitic acids. Fucoxanthinol and fucoxanthin were the major carotenoids in the M. squamiger dichloromethane extract. The methanol extract from $M$. squamiger exhibited $\mathrm{Cu}$ chelating properties, while both extracts were able to scavenge peroxyl free radicals. Overall, our results bring new insights into the possible use of S. spallanzanii and M. squamiger as sources of bioactive ingredients with different potential commercial applications, such as in the biomedical, food and feed areas. For 
example, S. spallanzanii biomass could be incorporated in fish feed as an attractant, while M. squamiger could be used as a taurine supplementation, in aquaculture.

Supplementary Materials: The following are available online at https:/ / www.mdpi.com/article / 10.3390/ani11123557/s1, Table S1: Linearity, limit of detection (LOD) and limit of quantification (LOQ) of FAME with the employed analytical conditions for carotenoids determination; Table S2 Regression equation, linearity, limit of detection (LOD) and limit of quantification (LOQ) of reference compounds with the employed analytical conditions for the carotenoid determination.

Author Contributions: Formal analysis, L.C.; Funding acquisition, L.C.; Investigation, Y.-L.P., M.J.R., C.G.P., R.C., I.M., A.R., F.F. and L.C.; Methodology, Y.-L.P., S.E. and L.C.; Project administration, L.C.; Resources, A.R., P.B.A. and L.C.; Supervision, L.C.; Writing-original draft, Y.-L.P.; Writing-review and editing, S.E., P.B.A., F.F. and L.C. All authors have read and agreed to the published version of the manuscript.

Funding: This work was supported by the Foundation for Science and Technology (FCT) and the Portuguese National Budget (UIDB/04326/2020 project). Luísa Custódio was supported by the FCT Scientific Employment Stimulus (CEECIND/00425/2017). F. Fernandes thanks FCT for funding through program DL 57/2016-Norma transitória (Ref. DL57/2016/CP1346/CT0018). Sofia Engrola acknowledges a FCT investigator grant (IF/00482/2014/CP1217/CT0005) funded by the European Social Fund, the Operational Programme Human Potential and FCT. Inês Mansinhos acknowledges FCT for the PhD grant SFRH/BD/145243/2019.

Institutional Review Board Statement: Not applicable.

Data Availability Statement: The dataset is available upon request from the corresponding author.

Acknowledgments: We acknowledge Carlos Afonso from the Fisheries, Biodiversity and Conservation research group (CCMAR), for the identification of the species used in this work.

Conflicts of Interest: The authors declare no conflict of interest.

\section{References}

1. Liu, L.; Zheng, Y.Y.; Shao, C.L.; Yun, C.; Wang, C.Y. Metabolites from marine invertebrates and their symbiotic microorganisms: Molecular diversity discovery, mining, and application. Mar. Life Sci. Technol. 2019, 1, 60-94. [CrossRef]

2. Luparello, C.; Mauro, M.; Lazzara, V.; Vazzana, M. Collective locomotion of human cells, wound healing and their control by extracts and isolated compounds from marine invertebrates. Molecules 2020, 25, 2471. [CrossRef] [PubMed]

3. Ahyong, S.; Kupriyanova, E.; Burghardt, I.; Sun, Y.; Hutchings, P.; Capa, M.; Cox, S. Phylogeography of the invasive Mediterranean fan worm, Sabella spallanzanii (Gmelin, 1791), in Australia and New Zealand. J. Mar. Biol. Assoc. UK 2017, 97, 985-991. [CrossRef]

4. Oliver, A.J.F.; Xavier, P.; Michael, T.; Leigh, T.; Lohrer Andrew, M. The Introduced fanworm, Sabella spallanzanii, alters soft sediment macrofauna and bacterial communities. Front. Ecol. Evol. 2019, 7, 481.

5. Von Ammon, U.; Wood, S.A.; Laroche, O.; Zaiko, A.; Lavery, S.D.; Inglis, G.J.; Pochon, X. Linking Environmental DNA and RNA for improved detection of the marine invasive Ffnworm Sabella spallanzanii. Front. Mar. Sci. 2019, 6, 621. [CrossRef]

6. Stabili, L.; Sicuro, B.; Daprà, F.; Gai, F.; Abete, C.; Dibenedetto, A.; Giangrande, A. The biochemistry of Sabella spallanzanii (Annelida: Polychaeta): A potential resource for the fish feed industry. J. World Aquac. Soc. 2013, 44, 384-395. [CrossRef]

7. Stabili, L.; Cecere, E.; Licciano, M.; Petrocelli, A.; Sicuro, B.; Giangrande, A. Integrated multitrophic aquaculture by-products with added value: The polychaete Sabella spallanzanii and the seaweed Chaetomorpha linum as potential dietary ingredients. Mar. Drugs 2019, 17, 12. [CrossRef]

8. Stabili, L.; Licciano, M.; Giangrande, A.; Fanelli, G.; Cavallo, R.A. Sabella spallanzanii filter-feeding on bacterial community: Ecological implications and applications. Mar. Environ. Res. 2006, 61, 74-92. [CrossRef]

9. Lušić, J.; Cvitković, I.; Despalatović, M.; Žunec, A.; Žuljević, A. Mediterranean fanworm, Sabella spallanzanii (Gmelin, 1791), as a potential biomonitor of trace metal pollution in the marine Environment. Chemosphere 2022, 287, 132123. [CrossRef]

10. Turon, X.; Nishikawa, T.; Rius, M. Spread of Microcosmus squamiger (Ascidiacea: Pyuridae) in the Mediterranean Sea and adjacent waters. J. Exp. Mar. Biol. Ecol. 2007, 342, 185-188. [CrossRef]

11. Rius, M.; Pascual, M.; Turon, X. Phylogeography of the widespread marine invader Microcosmus squamiger (Ascidiacea) reveals high genetic diversity of introduced populations and non-independent colonizations. Divers. Distrib. 2008, 14, 818-828. [CrossRef]

12. Rius, M.; Pineda, M.C.; Turon, X. Population dynamics and life cycle of the introduced ascidian Microcosmus squamiger in the Mediterranean Sea. Biol. Invasions 2009, 11, 2181-2194. [CrossRef]

13. Turon, X.; Nishikawa, T. Spread of Microcosmus squamiger in the Mediterranean Sea. In Proceedings of the International Invasive Sea Squirt Conference, Woods Hole, MA, USA, 21-22 April 2005. 
14. Mastrototaro, F.; Dappiano, M. New record of the non-indigenous species Microcosmus squamiger (Ascidiacea: Stolidobranchia) in the harbour of Salerno (Tyrrhenian Sea, Italy). Mar. Biodivers. Rec. 2005, 1, E12. [CrossRef]

15. Zenetos, A.; ÇIinar, M.E.; Pancucci-Papadopoulou, M.A.; Harmelin, J.G.; Furnari, G.; Andaloro, F.; Bellou, N.; Streftaris, N.; Zibrowius, $\mathrm{H}$. Annotated list of marine alien species in the Mediterranean with records of the worst invasive species. Med. Mar. Sci. 2005, 6, 63-118. [CrossRef]

16. Occhipinti-Ambrogi, A.; Marchini, A.; Cantone, G.; Castelli, A.; Chimenz, C.; Cormaci, M.; Froglia, C.; Furnari, G.; Gambi, M.C.; Giaccone, G.; et al. Alien species along the Italian coasts: An overview. Biol. Invasions 2011, 13, 215-237. [CrossRef]

17. Giangrande, A.; Pierri, C.; Del Pasqua, M.; Gravili, C.; Gambi MCGravina, M.F. The Mediterranean in check: Biological invasions in a changing sea. Mar. Ecol. 2020, 41, e12583. [CrossRef]

18. Onen, S.A. First occurrence of fouling ascidian species Microcosmus squamiger Michaelsen, 1927 and Didemnum ahu Monniot C. \& Monniot F., 1987 in İzmir Bay (Eastern Aegean Sea). J. Nat. Hist. 2020, 54, 1897-1912.

19. Tracy, B.M.; Larson, K.J.; Ashton, G.V.; Lambert, G.; Chang, A.L.; Ruiz, G.M. Northward range expansion of three non-native ascidians on the west coast of North America. BioInvasions Rec. 2017, 3, 203-209. [CrossRef]

20. Lambert, C.C.; Lambert, G. Persistence and differential distribution of nonindigenous ascidians in harbors of the Southern California Bight. Mar. Ecol. Prog. Ser. 2003, 259, 145-161. [CrossRef]

21. Rius, M.; Turon, X.; Pascual, M. Isolation of polymorphic microsatellite loci for the marine invader Microcosmus squamiger (Ascidiacea). Mol. Ecol. Res. 2008, 8, 1405-1407. [CrossRef]

22. Smith, M.J.; Dehnel, P.A. The composition of tunic from four species of ascidians. Comp. Biochem. Physiol. Part B Biochem. 1971, 40, 615-622. [CrossRef]

23. Ananthan, G.; Karthikeyan, M.M.; Selva, P.A.; Raghunathan, C. Studies on the seasonal variations in the proximate composition of ascidians from the Palk Bay, Southeast coast of India. Asian Pac. J. Trop. Biomed. 2012, 2, 793-797. [CrossRef]

24. Radhalakshmi, R.; Sivakumar, V.; Ali, H.A.J. Analysis of selected species of ascidians as bioindicators o metals in marine ecosystem. Int. J. Curr. Microbiol. Appl. Sci. 2014, 3, 755-764.

25. Meenakshi, V.K.; Gomathy, S.; Senthamarai, S. Analysis of vitamins by HPLC and phenolic compounds, flavonoids by HPTLC in Microcosmus exasperates. Eur. J. Zool. Res. 2012, 1, 105-110.

26. Giakoumi, S.; Katsanevakis, S.; Albano, P.G.; Azzurro, E.; Cardoso, A.C.; Cebrian, E.; Deidun, A.; Edelist Francour, D.P.; Jimenez, C.; Mačić, V.; et al. Management priorities for marine invasive species. Sci. Total Environ. 2019, 688, 976-982. [CrossRef]

27. Pinteus, S.; Lemos, M.F.; Alves, C.; Neugebauer, A.; Silva, J.; Thomas, O.P.; Botana, L.M.; Gaspar, H.; Pedrosa, R. Marine invasive macroalgae: Turning a real threat into a major opportunity-the biotechnological potential of Sargassum muticum and Asparagopsis armata. Algal Res. 2018, 34, 217-234. [CrossRef]

28. Pinteus, S.; Lemos, M.F.L.; Simões, M.; Alves, C.; Silva, J.; Gaspar, H.; Martins, A.; Rodrigues, A.; Pedrosa, R. Marine invasive species for high-value products' exploration-Unveiling the antimicrobial potential of Asparagopsis armata against human pathogens. Algal Res. 2020, 52, 102091. [CrossRef]

29. Pacheco, D.; Araújo, G.S.; Cotas, J.; Gaspar, R.; Neto, J.M.; Pereira, L. Invasive seaweeds in the Iberian Peninsula: A contribution for food supply. Mar. Drugs 2020, 18, 560. [CrossRef]

30. AOAC. Official Methods of Analysis; Association of Official Analytical Chemists: Arlington, VA, USA, 1990.

31. Pereira, H.; Barreira, L.; Custódio, L.; Alrokayan, S.; Mouffouk, F.; Varela, J.; Ben-Hamadou, R. Isolation and fatty acid profile of selected microalgae strains from the red sea for biofuel production. Energies 2013, 6, 2773-2783. [CrossRef]

32. Fernandes, F.; Barbosa, M.; Pereira, D.M.; Sousa-Pinto, I.; Valentão, P.; Azevedo, I.C.; Andrade, P.B. Chemical profiling of edible seaweed (Ochrophyta) extracts and assessment of their In Vitro effects on cell-free enzyme systems and on the viability of glutamate-injured SH-SY5Y cells. Food Chem. Toxicol. 2018, 116, 196-206. [CrossRef]

33. Fernandes, F.; Barbosa, M.; Oliveira, A.P.; Azevedo, I.C.; Sousa-Pinto, I.; Valentão, P.; Andrade, P. The pigments of kelps (Ochrophyta) as part of the flexible response to highly variable marine Environments. J. Appl. Phycol. 2016, 28, 3689-3696. [CrossRef]

34. Rodrigues, M.J.; Soszynski, A.; Martins, A.; Rauter, A.P.; Neng, N.R.; Nogueira, J.M.F.; Varela, J.; Barreira, L.; Custódio, L. Unravelling the antioxidant potential and the phenolic composition of organs of Limonium algarvense. Ind. Crops Prod. 2015, 77, 315-332. [CrossRef]

35. Gillespie, K.M.; Chae, J.M.; Ainsworth, E.A. Rapid measurement of total antioxidant capacity in plants. Nat. Prot. 2007, 2, 867-870. [CrossRef] [PubMed]

36. Lillebø, A.I.; Pita, C.; Rodrigues, J.; Ramos, S.; Villasante, S. How can marine ecosystem services support the Blue Growth agenda? Mar. Pol. 2017, 81, 132-142. [CrossRef]

37. Freitas, A.C.; Rodrigues, D.; Rocha-Santos, T.A.P.; Gomes, A.M.P.; Duarte, A.C. Marine biotechnology advances towards applications in new functional foods. Biotechnol. Adv. 2012, 30, 1506-1515. [CrossRef]

38. Martins, A.; Vieira, H.; Gaspar, H.; Santos, S. Marketed marine natural products in the pharmaceutical and cosmeceutical industries: Tips for success. Mar. Drugs 2014, 12, 1066-1101. [CrossRef]

39. Rodrigo, A.P.; Costa, P.M. The hidden biotechnological potential of marine invertebrates: The Polychaeta case study. Environ. Res. 2019, 173, 270-280. [CrossRef] 
40. Ganesan, A.R.; Mohanram, M.S.G.; Balasubramanian, B.; Kim, I.H.; Seedevi, P.; Mohan, K.; Kanagasabai, S.; Arasu, M.V.; Al-Dhabi, N.A.; Ignacimuthu, S. Marine invertebrates' proteins: A recent update on functional property. J. King Saud Univ.-Sci. 2020, 32, 1496-1502. [CrossRef]

41. Rocha, J.; Peixe, L.; Gomes, N.C.M.; Calado, R. Cnidarians as a source of new marine bioactive compounds-An overview of the last decade and future steps for bioprospecting. Mar. Drugs 2011, 9, 1860-1886. [CrossRef]

42. Pinteus, S.; Lemos, M.F.L.; Alves, C.; Silva, J.; Rui Pedrosa, R. The marine invasive seaweeds Asparagopsis armata and Sargassum muticum as targets for greener antifouling solutions. Sci. Total Environ. 2021, 750, 141272. [CrossRef]

43. Meena, B.; Anburajan, L.; Nitharsan, K.; Vinithkuma, N.V.; Dharani, G. Taxonomic composition and biological activity of bacterial communities associated with marine Ascidians from Andaman Islands, India. Appl. Biochem. Biotechnol. 2021, 193, 2932-2963. [CrossRef]

44. Pombo, A.; Baptista, T.; Granada, L.; Ferreira, S.M.F.; Gonçalves, S.C.; Anjos, C.; Costa, J.L. Insight into aquaculture's potential of marine annelid worms and ecological concerns: A review. Rev. Aquac. 2020, 12, 107-121. [CrossRef]

45. Glencross, B.D.; Booth, M.; Allan, G.L. A feed is only as good as its ingredients-A review of ingredient evaluation strategies for aquaculture feeds. Aquac. Nut. 2007, 13, 17-34. [CrossRef]

46. Yang, Y.; Xie, S.; Cui, Y.; Lei, W.; Zhu, X.; Yang, Y.; Yu, Y. Effect of replacement of dietary fish meal by meat and bone meal and poultry by-product meal on growth and feed utilization of gibel carp, Carassius auratus gibelio. Aquac. Nut. 2004, 10, 289-294. [CrossRef]

47. Roy, S.S.; Pal, R. Microalgae in aquaculture: A review with special references to nutritional value and fish dietetics. Proc. Zool. Soc. 2015, 68, 1-8. [CrossRef]

48. Prabu, E.; Felix, S.; Felix, N.; Ahilan, B.; Ruby, P. An overview on significance of fish nutrition in aquaculture industry. Int. J. Fish. Aquat. Stud. 2017, 5, 349-355.

49. Miles, R.D.; Chapman, F.A. The Benefits of Fish Meal in Aquaculture Diets; University of Florida IFAS Extension: Gainesville, FL, USA, 2015; p. 6.

50. Jeong, B.-Y.; Choi, B.-D.; Moon, S.-K.; Lee, J.-S.; Jeong, W.-G.; Kim, P.-H. Proximate composition and sterol content of 35 species of marine invertebrates. Korean J. Fish. Aquat. Sci. 1999, 32, 192-197.

51. Oliveira, A.R.; Sykes, A.V.; Hachero-Cruzado, I.; Azeiteiro, U.M.; Esteves, E. A sensory and nutritional comparison of mussels (Mytilus sp.) produced in NW Iberia and in the Armona offshore production area (Algarve, Portugal). Food Chem. 2015, 168, 520-528. [CrossRef]

52. USDA. National Nutrient Database for Standard Reference, Legacy Release; United States Department of Agriculture-Agricultural Research Service: Washington, DC, USA, 2021.

53. Wu, G.; Morris, S.M., Jr. Arginine metabolism: Nitric oxide and beyond. Biochem. J. 1998, 336, 1-17. [CrossRef]

54. Rajapakse, N.W.; Mattson, D.L. Role of L-Arginine in nitric oxide production in health and hypertension. Clin. Exp. Pharmacol. Physiol. 2009, 36, 249-255. [CrossRef]

55. Chin-Dusting, J.P.F.; Willems, L.; Kaye, D.M. L-Arginine transporters in cardiovascular disease: A novel therapeutic target. Pharmacol. Ther. 2007, 116, 428-436. [CrossRef]

56. Ikeda, A.; Imaizumi, K.; Sugano, M. Interaction of dietary protein and fat on plasma cholesterol and amino acid levels, fatty acid desaturation, and prostacyclin production in exogenous hypercholesterolemic rats. Biosci. Biotechnol. Biochem. 1993, 57, 1867-1872. [CrossRef]

57. Luo, Z.; Liu, Y.; Mai, K.; Tian, L. Advance in research on arginine requirement for fish: A review. Shuichan Xuebao 2004, 28, 450-459.

58. Borlongan, I.G. Arginine and threonine requirements of milkfish (Chanos chanos Forsskal) juveniles. Aquaculture 1991, 93, 313-322. [CrossRef]

59. Berge, G.E.; Lied, E.; Sveier, H. Nutrition of Atlantic salmon (Salmo salar): The requirement and metabolism of arginine. Comp. Biochem. Physiol. 1997, 117, 501-509. [CrossRef]

60. Alam, M.S.; Teshima, S.I.; Koshio, S.; Ishikawa, M. Arginine requirement of juvenile Japanese flounder Paralichthys olivaceus estimated by growth and biochemical parameters. Aquaculture 2002, 205, 127-140. [CrossRef]

61. Buentello, J.A.; Gatlin, D.M. The dietary arginine requirement of channel catfish (Ictalurus punctatus) is influenced by endogenous synthesis of arginine from glutamic acid. Aquaculture 2000, 188, 311-321. [CrossRef]

62. Chow, M.; Boyd, C.D.; Iruela-Arispe, M.L.; Wrenn, D.S.; Mecham, R.; Helene Sage, E. Characterization of elastin protein and mRNA from salmonid fish (Oncorhynchus kisutch). Comp. Biochem. Physiol.-Part B Biochem. 1989, 93, 835-845. [CrossRef]

63. Li, P.; Wu, G. Roles of dietary glycine, proline, and hydroxyproline in collagen synthesis and animal growth. Amino Acids 2018, 50, 29-38. [CrossRef]

64. Debelle, L.; Tamburro, A.M. Elastin: Molecular description and function. Int. J. Biochem. Cell Biol. 1999, 31, 261-272. [CrossRef]

65. Li, P.; Mai, K.; Trushenski, J.; Wu, G. New developments in fish amino acid nutrition: Towards functional and Environmentally oriented aquafeeds. Amino Acids 2009, 37, 43-53. [CrossRef] [PubMed]

66. Xie, S.-W.; Tian, L.-X.; Jin, Y.; Yang, H.-J.; Liang, G.-Y.; Liu, Y.-J. Effect of glycine supplementation on growth performance, body composition and salinity stress of juvenile Pacific white shrimp, Litopenaeus vannamei fed low fishmeal diet. Aquaculture 2014, 418-419, 159-164. [CrossRef] 
67. Xie, S.; Zhou, W.; Tian, L.; Niu, J.; Liu, Y. Effect of N-acetyl cysteine and glycine supplementation on growth performance, glutathione synthesis, anti-oxidative and immune ability of Nile tilapia, Oreochromis niloticus. Fish Shellfish Immunol. 2016, 55, 233-241. [CrossRef] [PubMed]

68. Murai, T.; Sumalangkay, A.; Pascual, F.P. Improvement of diet attractability for Penaeus monodon by supplementing various attractants. In SEAFDEC Aquaculture Department Quarterly Research Report; SEAFDEC Aquaculture Department: Tigbauan, Philippines, 1981; Volume 5, pp. 1-4.

69. Smith, D.M.; Tabrett, S.J.; Barclay MCIrvin, S.J. The efficacy of ingredients included in shrimp feeds to stimulate intake. Aquac. Nutr. 2005, 11, 263-272. [CrossRef]

70. Dragnes, B.T.; Larsen, R.; Ernstsen, M.H.; Mæhre, H.; Elvevoll, E.O. Impact of processing on the taurine content in processed seafood and their corresponding unprocessed raw materials. Int. J. Food Sci. Nutr. 2009, 60, 143-152. [CrossRef]

71. El-Sayed, A.M. Is dietary taurine supplementation beneficial for farmed fish and shrimp? A comprehensive review. Rev. Aquac. 2014, 6, 241-255. [CrossRef]

72. Sampath, W.W.H.A.; Rathnayake, R.M.D.S.; Yang, M.; Zhang, W.; Mai, K. Roles of dietary taurine in fish nutrition. Mar. Life Sci. Technol. 2020, 2, 360-375. [CrossRef]

73. Shen, G.P.; Haung, Y.; Dong, J.Y.; Wang, X.X.; Cheng, K.K.; Feng, J.H.; Xu, J.J.; Ye, J.D. Metabolic effect of dietary taurine supplementation on Nile tilapia (Oreochromis nilotictus) evaluated by NMR-based metabolomics. J. Agric. Food Chem. 2018, 66, 368-377. [CrossRef]

74. Gaylord, T.G.; Teague, A.M.; Barrows, F.T. Taurine supplementation of all-plant protein diets for rainbow trout (Oncorhynchus mykiss). J. World Aquac. Soc. 2006, 37, 509-517. [CrossRef]

75. Shiau, S.; Chou, B. Grass shrimp, Penaeus monodon, growth as influenced by dietary taurine supplementation. Comp. Biochem. Physiol. Part A Physiol. 1994, 108, 137-142.

76. Murata, H. The green liver syndrome is caused by taurine deficiency in yellowtail, Seriola quinqueradiata fed diets without fishmeal. Aquac. Sci. 2005, 53, 279-290.

77. Takagi, S.; Murata, H.; Goto, T.; Ichiki, T.; Endo, M.; Hatate, H.; Ukawa, M. Efficacy of taurine supplementation for preventing green liver syndrome and improving growth performance in yearling red sea bream Pagrus major fed low-fishmeal diet. Fish. Sci. 2006, 72, 1191-1199. [CrossRef]

78. Yokoyama, M.; Takeuchi, T.; Park, G.S.; Nakazoe, J. Hepatic cysteinesulphinate decarboxylase activity in fish. Aquac. Res. 2001, 32, 216-220. [CrossRef]

79. Salze, G.P.; Davis, D.A. Taurine: A critical nutrient for future fish feeds. Aquaculture 2015, 437, 215-229. [CrossRef]

80. Spitze, A.R.; Wong, D.L.; Rogers, Q.R.; Fascetti, A.J. Taurine concentrations in animal feed ingredients; cooking influences taurine content. J. Anim. Physiol. Anim. Nutr. 2003, 87, 251-262. [CrossRef]

81. Schaffer, S.; Kim, H. Effects and mechanisms of taurine as a therapeutic agent. Bimol. Ther. 2018, 26, 225-241. [CrossRef]

82. $\mathrm{Wu}, \mathrm{G}$. Important roles of dietary taurine, creatine, carnosine, anserine and 4-hydroxyproline in human nutrition and health. Amino Acid 2020, 52, 329-360. [CrossRef]

83. Hou, Y.; He, W.; Hu, S.; Wu, G. Composition of polyamines and amino acids in plant-source foods for human consumption. Amino Acid 2019, 51, 1153-1165. [CrossRef]

84. McCusker, S.; Buff, P.R.; Yu, Z.; Fascetti, A.J. Amino acid content of selected plant, algae and insect species: A search for alternative protein sources for use in pet foods. J. Nutr. Sci. 2014, 3, e39. [CrossRef]

85. Ra, S.G.; Choi, Y.; Akazawa, N.; Kawanaka, K.; Ohmori, H.; Maeda, S. Effects of taurine supplementation on vascular endothelial function at rest and after resistance exercise. Adv. Exp. Med. Biol. 2019, 1155, 407-414.

86. Sak, D.; Erdenen, F.; Müderrisoglu, C.; Altunoglu, E.; Sozer, V.; Gungel, H.; Guler, P.A.; Sak, T.; Uzun, H. The relationship between plasma taurine levels and diabetic complications in patients with Type 2 diabetes mellitus. Biomolecules 2019, 11, 96. [CrossRef]

87. Nikkhah, E.; Shirani, K.; Rezaee, R.; Karimi, G. Protective effects of taurine against hepatotoxicity induced by pharmaceuticals and Environmental chemicals. Toxicol. Environ. Chem. 2021, 103, 56-84. [CrossRef]

88. Backus, R.C.; Ko, K.S.; Fascetti, A.J.; Kittleson, M.D.; Macdonald, K.A.; Maggs, D.J.; Berg, J.R.; Rogers, Q.R. Low plasma taurine concentration in Newfoundland dogs is associated with low plasma methionine and cyst(e)ine concentrations and low taurine synthesis. J. Nutr. 2006, 136, 2525-2533. [CrossRef]

89. Kaplan, J.L.; Stern, J.A.; Fascetti, A.J.; Larsen, J.A.; Skolnik, H.; Peddle, G.D.; Kienle, R.D.; Waxman, A.; Cocchiaro, M.; GuntherHarrington, C.T.; et al. Taurine deficiency and dilated cardiomyopathy in golden retrievers fed commercial diets. PLoS ONE 2018, 13, e0210233.

90. Quilliam, C.; Ren, Y.; Morris, T.; Ai, Y.; Weber, L.P. The Effects of 7 days of feeding pulse-based diets on digestibility, glycemic response and taurine levels in domestic dogs. Front. Vet. Sci. 2021, 8, 654223. [CrossRef] [PubMed]

91. Basili, M.; Pedro, B.; Hodgkiss-Geere, H.; Navarro-Cubas, X.; Graef, N.; Dukes-McEwan, J. Low plasma taurine levels in English cocker spaniels diagnosed with dilated cardiomyopathy. J. Small Anim. Pract. 2021, 62, 570-579. [CrossRef] [PubMed]

92. Hossain, M.A.; Masayuki Furuichi, M. Essentiality of dietary calcium supplement in fingerling scorpion fish Sebastiscus marmoratus. Aquaculture 2000, 189, 155-163. [CrossRef]

93. Sugiura, S.H.; Hardy, R.W.; Roberts, R.J. The pathology of phosphorus deficiency in fish-A review. J. Fish Dis. 2004, 27, 255-265. [CrossRef] 
94. Hossai, M.A.; Furuichi, M. Essentiality of dietary calcium supplement in redlip mullet Liza haemmatocheila. Aquacul. Nutr. 2000, 6, 33-38. [CrossRef]

95. Bury, N.; Grosell, M. Iron acquisition by teleost fish. Comp. Biochem. Physiol. 2003, 135, 97-105. [CrossRef]

96. Ueki, T.; Yamaguchi, N.; Isago, Y.R.; Tanahashi, H. Vanadium accumulation in ascidians: A system overview. Coord. Chem. Rev. 2015, 301, 300-308. [CrossRef]

97. Sepe, A.; Ciaralli, L.; Ciprotti, M.; Giordano, R.; Funari, E.; Costantini, S. Determination of cadmium, chromium, lead and vanadium in six fish species from the Adriatic Sea. Food Addit. Contam. 2003, 20, 543-552. [CrossRef]

98. Helaly, O.; Abd El-Ghany, M.; Borai, E.; Aly, H.F.; Fattah, T.M.A. Separation of cerium, light and heavy rare earth concentrates from Egyptian crude monazite. Chem. Tech. Ind. J. 2015, 10, 184-192.

99. Ryabchikov, D.I.; Gol'Braikh, E.K. The Analytical Chemistry of Thorium: International Series of Monographs on Analytical Chemistry; Elsevier: Amsterdam, The Netherlands, 2013; Volume 10.

100. Veado, M.A.R.V.; Abrantes, I.A.; Oliveira, A.H.; Almeida, M.R.M.G.; Miguel, R.A.; Severo, M.I.; Cabaleiro, H.L. Metal pollution in the Environment of Minas Gerais state-Brazil. Environ. Monit. Assess. 2006, 117, 157-172. [CrossRef]

101. Peng, C.; Ma, Y.; Ding, Y.; He, X.; Zhang, P.; Lan, T.; Wang, D.; Zhang, Z.; Zhang, Z. Influence of speciation of thorium on toxic effects to green algae Chlorella pyrenoidosa. Int. J. Mol. Sci. 2017, 18, 795. [CrossRef]

102. Stricht, E.V.D.; Kirchmann, R. Radioecology; Radioactivity \& Ecosystems: Liege, Belgium, 2001; pp. $219-303$.

103. Yilmaz, M.; Ozmen, S.F. Radiological risk assessment of fish feed and feed raw materials. Aquac. Res. 2020, 51, $2190-2196$. [CrossRef]

104. Szefer, P.; Wenne, R. Concentration of uranium and thorium in molluscs inhabiting Gdansk bay, Baltic sea. Sci. Total Environ. 1987, 65, 191-202. [CrossRef]

105. Szefer, P.; Szefer, K.; Falandysz, J. Uranium and thorium in muscle tissue of fish taken from the southern Baltic. Helgoländer Meeresunters. 1990, 44, 31-38. [CrossRef]

106. Giangrande, A.; Cavallo, A.; Licciano, M.; Mola, E.; Pierri, C.; Trianni, L. Utilization of the filter feeder polychaete Sabella spallanzanii Gmelin (Sabellidae) as bioremediator in aquaculture. Aquac. Int. 2005, 13, 129-136. [CrossRef]

107. Carvalho, C.C.C.R.; Caramujo, M.J. The various roles of fatty acids. Molecules 2018, 23, 2583. [CrossRef]

108. Betancor, M.B.; MacEwan, A.; Sprague, M.; Gong, X.; Montero, D.; Han, L.; Napier, J.A.; Norambuena, F.; Izquierdo, M.; Tocher, D.R. Oil from transgenic Camelina sativa as a source of EPA and DHA in feed for European sea bass (Dicentrarchus labrax L.). Aquaculture 2021, 530, 735759. [CrossRef]

109. Wijendram, V.; Hayes, K.C. Dietary n-6 and n-3 fatty acid balance and cardiovascular health. Annu. Rev. Nutr. 2004, 24, 597-615. [CrossRef]

110. Lee, S.; Lee, J.; Choi, I.J.; Kim, Y.-W.; Ryu, K.W.; Kim, Y.-I.; Kim, J. Dietary n-3 and n-6 polyunsaturated fatty acids, the FADS gene, and the risk of gastric cancer in a Korean population. Sci. Rep. 2018, 8, 3823. [CrossRef]

111. Russo, E.; Giudici, F.; Fiorindi, C.; Ficari, F.; Scaringi, S.; Amedei, A. Immunomodulating activity and therapeutic effects of short chain fatty acids and tryptophan post-biotics in inflammatory bowel disease. Front. Immunol. 2019, 10, 2754. [CrossRef]

112. Wall, R.; Ross, R.P.; Fitzgerald, G.F.; Stanton, C. Fatty acids from fish: The anti-inflammatory potential of long-chain omega-3 fatty acids. Nutr. Rev. 2010, 68, 280-289. [CrossRef]

113. Simopoulos, A.P. Evolutionary aspects of the dietary omega-6:omega-3 fatty acid ratio: Medical implications. World Rev. Nutr Diet. 2009, 100, 1-21.

114. WHO. Fats and Fatty Acids in Human in Nutrition. 2008. Available online: https://apps.who.int/nutrition/publications/ nutrientrequirements/anm_fatsandfattyacids_human_nut/en/index.html (accessed on 2 September 2021).

115. Galasso, C.; Corinaldesi, C.; Sansone, C. Carotenoids from marine organisms: Biological functions and industrial applications. Antioxidants 2017, 6, 96. [CrossRef]

116. Matsuno, T. Aquatic animal carotenoids. Fish. Sci. 2001, 67, 771-783. [CrossRef]

117. Tsushima, M.; Matsuno, T. Comparative biochemical studies of carotenoids in sea-urchins-I. Comp. Biochem. Physiol. Part B Comp. Biochem. 1990, 96, 801-810. [CrossRef]

118. D’Orazio, N.; Gemello, E.; Gammone, M.A.; de Girolamo, M.; Ficoneri, C.; Riccioni, G. Fucoxantin: A treasure from the sea. Mar. Drugs 2012, 10, 604-616. [CrossRef]

119. Terasaki, M.; Inoue, T.; Murase, W.; Kubota, A.; Kojima, H.; Kojoma, M.; Ohta, T.; Maeda, H.; Miyashita, K.; Mutoh, M.; et al. Fucoxanthinol induces apoptosis in a pancreatic intraepithelial neoplasia cell line. Cancer Genom. Proteom. 2021, 18, 133-146. [CrossRef] [PubMed]

120. Borodina, A.V.; Maoka, T. The composition of carotenoids in tissues of the ascidian Botryllus schlosseri (Pallas, 1766) from the Black Sea. Russia J. Mar. Biol. 2018, 44, 226-231. [CrossRef]

121. Kotake-Nara, E.; Kushiro, M.; Zhang, H.; Sugawara, T.; Miyashita, K.; Nagao, A. Carotenoids affect proliferation of human prostate cancer cells. J. Nutr. 2001, 131, 3303-3306. [CrossRef] [PubMed]

122. Sun, P.; Wong, C.-C.; Li, Y.; He, Y.; Mao, X.; Wu, T.; Ren, Y.; Chen, F. A novel strategy for isolation and purification of fucoxanthinol and fucoxanthin from the diatom Nitzschia laevis. Food Chem. 2019, 277, 566-572. [CrossRef]

123. Lu, X.; Sun, H.; Zhao, W.; Cheng, K.-W.M.; Chen, F.; Liu, B. A hetero-photoautotrophic two-stage cultivation process for production of fucoxanthin by the marine diatom Nitzschia laevis. Mar. Drugs 2018, 16, 219. [CrossRef] 
124. Li, Y.; Liu, L.; Sun, P.; Zhang, Y.; Wu, T.; Sun, H.; Cheng, K.-W.; Chen, F. Fucoxanthinol from the diatom Nitzschia Laevis ameliorates neuroinflammatory responses in lipopolysaccharide-stimulated BV-2 microglia. Mar. Drugs 2020, 18, 116.

125. MarketsandMarkets. 2021. Available online: https://www.marketsandmarkets.com (accessed on 10 September 2021).

126. Nakano, T.; Wiegertjes, G. Properties of carotenoids in fish fitness: A Review. Mar. Drugs 2020, 18, 568. [CrossRef]

127. Livingstone, D.R. Oxidative stress in aquatic organisms in relation to pollution and aquaculture. Rev. Med. Vet. 2003, 154, 427-430.

128. Sinha, A.K.; Matey, V.; Giblen, T.; Blust, R.; De Boeck, G. Gill remodeling in three freshwater teleosts in response to high Environmental ammonia. Aquat. Toxicol. 2014, 155, 166-180. [CrossRef]

129. Abdel-Tawwab, M.; El-Sayed, G.O.; Monier, M.N.; Shady, S.H. Dietary EDTA supplementation improved growth performance, biochemical variables, antioxidant response, and resistance of Nile tilapia, Oreochromis niloticus (L.) to Env ironmental heavy metals exposure. Aquaculture 2017, 473, 478-486. [CrossRef]

130. Mamelona, J.; Pelletier, É.; Girard-Lalancette, K.; Legault, J.; Karboune, S.; Kermasha, S. Quantification of phenolic contents and antioxidant capacity of Atlantic sea cucumber, Cucumaria frondosa. Food Chem. 2007, 104, 1040-1047. [CrossRef]

131. Aklakur, M. Natural antioxidants from sea: A potential industrial perspective in aquafeed formulation. Rev. Aquac. 2018, 10, 385-399. [CrossRef]

132. Chen, Y.J.; Liu, Y.J.; Tian, L.X.; Niu, J.; Liang, G.Y.; Yang, H.J.; Zhang, Y.Q. Effect of dietary vitamin and selenium supplementation on growth, body composition, and antioxidant defense mechanism in juvenile largemouth bass (Micropterus salmoide) fed oxidized fish oil. Fish Physiol. Biochem. 2013, 39, 593-604. [CrossRef]

133. Wawrzyniak, M.K.; Serrato, L.A.M.; Blanchoud, S. Artificial seawater based long-term culture of colonial ascidians. Dev. Biol. 2021, 480, 91-104. [CrossRef] 